\title{
Test Plan, The Czechowice Oil Refinery Bioremediation Demonstration of a Process Waste Lagoon
}

by

D. J. Altman

Westinghouse Savannah River Company

Savannah River Site

Aiken, South Carolina 29808

K. H. Lombard

T. C. Hazen

\section{RECEIVED \\ JUL 211999 \\ OSTI}

This paper was prepared in connection with work done under the above contract number with the $U$. $S$. Department of Energy. By acceptance of this paper, the publisher and/or recipient acknowledges the U.S. Government's right to retain a nonexclusive, royalty-free license in and to any copyright covering this paper, along with the right to reproduce and to authorize others to reproduce all or part of the copyrighted paper. 


\section{DISCLAIMER}

Portions of this document may be illegible electronic image products. Images are produced from the best available original document. 


\section{DISCLAIMER}

This report was prepared as an account of work sponsored by an agency of the United States Government. Neither the United States Government nor any agency thereof, nor any of their employees, makes any warranty, express or implied, or assumes any legal liability or responsibility for the accuracy, completeness, or usefulness of any information, apparatus, product, or process disclosed, or represents that its use would not infringe privately owned rights. Reference herein to any specific commercial product, process, or service by trade name, trademark, manufacturer, or otherwise does not necessarily constitute or imply its endorsement, recommendation, or favoring by the United States Government or any agency thereof. The views and opinions of authors expressed herein do not necessarily state or reflect those of the United States Government or any agency thereof.

This report has been reproduced directly from the best available copy.

Available to DOE and DOE contractors from the Office of Scientific and Technical Information, P. O. Box 62, Oak Ridge, TN 37831; prices available from (423) 576-8401.

Available to the public from the National Technical Information Service, U. S. Department of Commerce, 5285 Port Royal Road, Springfield, VA 22161. 


\title{
TEST PLAN
}

\author{
THE CZECHOWICE OIL REFINERY
} BIOREMEDIATION DEMONSTRATION OF A PROCESS WASTE LAGOON CZECHOWICE-DZIEDZICE, POLAND

DOE/OTD TTP No: SR-1-6-PL-21-(U)

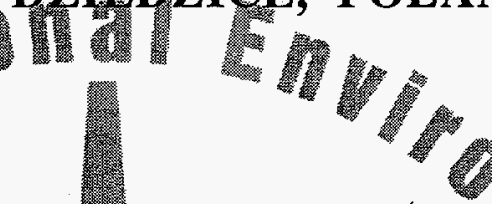

Publication Date: March 31, 1997 Revision: 0

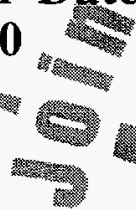

Kenneth
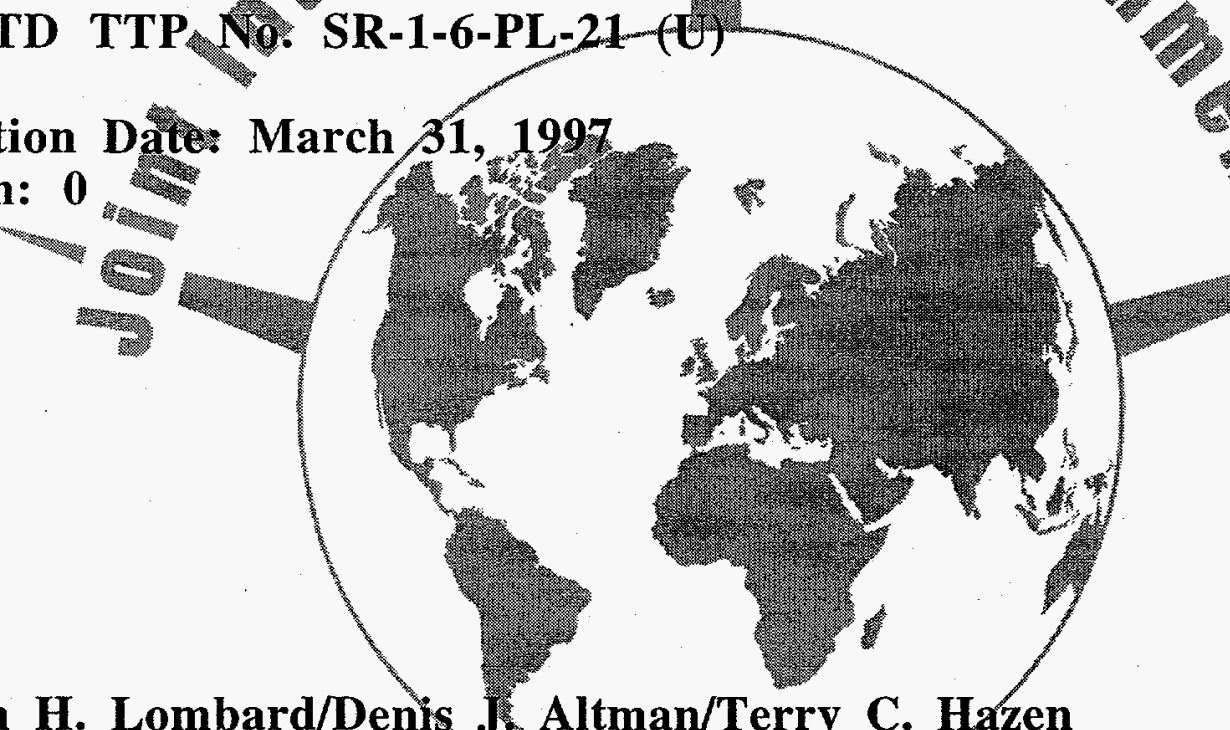

Savannah River Technology Center Environmental Science \& Technology-Department. Environmental Biotechnology Section

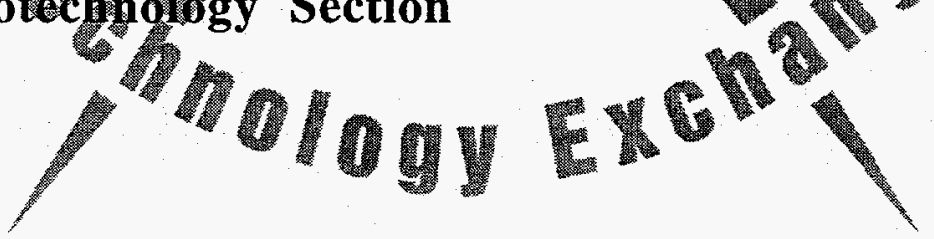

WESTINGHOUSE SAVANNAH RIVER COMPANY

SAVANNAH RIVER SITE

Aiken, South Carolina 29808 


\section{Disclaimer}

This report was prepared as an account of work sponsored by an agency of the United States Government. Neither the United States Government nor any agency thereof, nor any of their employees, make any warranty, express or implied, or assumes any liability or responsibility for the accuracy, completeness, or usefulness of any information, apparatus, product, or process disclosed, or represents that its use would not infringe privately owned rights. Reference herein to any specific commercial product, process or service by trade name, trademark, manufacturer, or otherwise does not necessarily constitute or imply its endorsement, recommendation, or favoring by the United States Government or any agency thereof. The views and opinions of the authors expressed herein do not necessarily state or reflect those of the United States Government or any agency thereof.

... $\quad: \quad 1$,

\section{Acknowledgments}

The information contained in this Test Plan was developed during the course of work for the Westinghouse Savannah River Company under Contact No. DE-AC09-89R180035 with the U.S. Department of Energy. In addition, the authors would like to thank the following organizations and personnel for having made significant contributions to the success of this demonstration: The Polish Institute for Ecology of Industrial Areas, Bioremediation Demonstration Team; $M$. M. Franck, C. B. Fliermans and C. J. Berry from the Savannah River Technology Center, Environmental Biotechnology Section; HydroLab® Corporation for their generous contribution of equipment. Florida State University, Risk Assessment Team; Ames Laboratory, ESC Team; The Czechowice Oil Refinery and their engineering staff; and Dr. Terry Hazen for his continued support, guidance and personal efforts in the research and development of innovative bioremediation technologies. 
2.2 Technical Need

2.3 Technology Description

2.4 Benefits

\subsection{Alternatives}

2.6 Site Description and Area Maps

FIGURE 2-1 BACTERIAL OXIDATION PATHWAY OF NAPHTHALENE TO CATECHOL (ATLAS 1984)

FIGURE 2-2 POLAND AND KATOWICE/BIELSKO-BIALA REGIONAL MAP

FIGURE 2-3 KATOWICE/CZECHOWICE-DZIEDZICE REGIONAL MAP

FIGURE 2-4 REFINERY LOCATION MAP

FIGURE 2-5 REFINERY LAGOONS

\section{TEST PLAN}

3.1 Criteria for Success

\subsection{Biopile Description}

3.2.1 Biopile Design and Construction

3.2.2 System Performance

3.2.3 Cost Analysis

\subsection{Process Monitoring}

3.3.1 Monitoring Equipment

\section{SAMPLING AND ANALYSIS}

\subsection{Soil Sampling Protocol}

4.2 Soil Gas Sampling Protocols

\subsection{Groundwater Sampling Protocols}

4.4 Analytical Procedures 
Czechowice Oil Refinery

Bioremediation Demonstration

Test Plan
WSRC-RP-97-214 Revision: 0

4.5.1 Acridine Orange Direct Counts (AODC)

4.5.2 Aerobic Heterotrophic Plate Count

4.5.3 TPH Enrichment

5. HEALTH AND SAFETY

5.1 Other Safety Information.

5.2 Security

6. PATENTS

7. REFERENCES

Appendices

Appendix A List of Acronyms and Abbreviations 56

Appendix B Conceptual Biopile Design

Appendix C Health And Safety Plan 


\section{TEST PLAN SUMMARY}

The remediation strategies that will be applied at the Czechowice Oil Refinery waste lagoon in Czechowice, Poland are designed, managed and implemented under the direction of the Westinghouse Savannah River Company (WSRC) for the United States Department of Energy (DOE). WSRC will be assisted in the demonstration by The Institute for Ecology of Industrial Areas (IETU). This collaboration between IETU and DOE will provide the basis for international technology transfer of new and innovative remediation technologies that can be applied in Poland and the Eastern European Region as well.

The Czechowice Oil Refinery Project will bring together several proven techniques and remediation tools used by WSRC to remove and/or destroy contaminants, via biostimulation of indigenous microbes found in the environment. The strategies employed will include bioremediation, using the natural cleansing capacity of the environment to degrade the hydrocarbon pollutants. A risk based approach will guide the final selection and remedial design. This approach provides a plan that will take into account the intended future use of the site and emphasizes the natural cleansing methods whenever possible. More aggressive techniques could be taken for sites that are to be developed for future uses that would involve higher potential exposure risks.

A treatability study of the lagoon's waste and soil will determine the physical and chemical parameters necessary to maintain and stimulate an active microbial community that can sustain a high biodegradation rate of the contaminants. The treatability study, along with the characterization data will 
provide the information necessary to design and deploy a bioremediation system capable of producing the stimulus necessary to maintain the biological activity needed to degrade the contaminants to less toxic levels.

This unprecedented Polish initiative will be a showcase for United States based environmental technologies, with a strong emphasis placed on the United States Department of Energy/EM 50 developed tools. A technology information exchange will be highlighted through presentations, workshops and tours of the Czechowice Oil Refinery project. In a special session, at the Warsaw '96 Symposium, dedicated in part to bioremediation technology developed for DOE by WSRC, US vendors (and others) that participated in the project will have an opportunity to present and display their products. A strong focus will be given to technology transfer, not only at the symposium but during the multiple windows of opportunity that will exist throughout this project. 


\section{Introduction}

This test plan has been prepared as the guidance document for the design, construction, start-up and operations phases of a bioremediation demonstration to be performed at the Czechowice Oil Refinery S.A., in Czechowice-Dziedzice, Poland. Bioremediation is generally attempted by employing biostimulation, a process in which the conditions for microbial growth are optimized by supplying adequate amounts of electron acceptor(s), water, nutrients, in the form of nitrogen, phosphorus and trace elements, to the contaminated material. Because biodegradation rates for petroleum hydrocarbons are fastest under aerobic conditions, maintaining adequate oxygen levels and moisture control are two of the main objectives associated with this project.

The process waste lagoon selected for the technology demonstration contains petroleum sludges, soils contaminated with crude and processed oil and other petroleum by-products and process waste from the refining of crude oil. The predominant contaminants of concern (COCs) are polycyclic aromatic hydrocarbons (PAHs) including benzo(a)pyrene, a known carcinogen. Also benzene, toluene, ethylbenzene and xylene known as BTEX and very recalcitrant high molecular weight molecules, the remnants and residue from tank bottoms of acid refining of crude oil. Although the high molecular weight molecules represent a large portion of the total petroleum hydrocarbons (TPH) present in the waste material, it is of less concern to human health and the environment from a risk assessment stand point, due to their highly insoluble state and lack of mobility within a soil matrix. The bioremediation processes will however, 
reduce even the highly recalcitrant substances found in the waste material over time.

The petroleum sludges and contaminated material present several unique challenges to the remediation effort. The refinery and its associated lagoons are over one hundred years old, creating highly weathered conditions and material that will require special handling and preparation for the remediation process to be effective. The integrated bioremediation system (biopile), as designed, will provide the necessary stimulation needed to support the biological processes required to break down the recalcitrant hydrocarbon complex to a more innocuous and stable material.

The $\mathrm{pH}$ of the contaminated material ranges from 4 to $\leq 1$. This was, at first, considered to be problematic in the design of the biological remediation system, but preliminary data from the ongoing treatability study, being conducted by IETU staff, clearly shows that the TPH can be biodegraded by $90 \%$ in 21 days with the addition of air as an oxygen source ( $\mathrm{e}^{-}$acceptor), a slight adjustment of the $\mathrm{pH}$ by the addition of dolomite $\left[\mathrm{CaMg}\left(\mathrm{CO}_{3}\right)_{2}\right]$ as a buffering agent and minimal nutrients ( $\mathrm{N}$ and $\mathrm{P}$ ). Additionally, due to the chemical composition of dolomite, ion exchange rates are increased, particularly in the clays, thereby increasing the permeability. Thus, an increase in the bioavailability of the contaminants. Further details on this chemical interaction can be found in the design details in section 3.2 .1 of the test plan.

Dolomite was selected over other materials e.g., fly ash, as a $\mathrm{pH}$ buffer and structural stabilizer based on several other factors including its ease of handling, relative low cost and availability, and a direct and inexpensive transportation 
route via train from the quarry to the refinery. Dolomite is also available in a variety of screen sizes which will be incorporated into the process design providing excellent stabilization characteristics and improved permeability necessary for an effective air distribution throughout the system. Contrary to this, fly ash is a fine dusty powder with approximately $70 \%$ of the fines passing a $63-71 \mu \mathrm{m}$ screen and an average particle size density of $2400 \mathrm{~kg} / \mathrm{m}^{3}$ dry wt. (Laczny 1983). The small particle size will increase the potential for system plugging and abrasion on the wearing surface of pumps and other system components. Although the cost of fly ash may be less expensive, based on the value of the material (zero value), the availability of appropriate transportation methods may drive the cost above that of dolomite. Normally, transportation costs associated with the shipment of large quantities of this type of material are on a per ton basis.

The final site use, proposed by the refinery, for the lagoons is a "green belt" to serve as a buffer zone and visual barrier between the refinery and the city of Czechowice-Dziedzice. The green belt will have limited access by trained refinery and IETU personnel for scientific and research purposes and for continued monitoring of the biopile processes. The area is not intended for recreational use by the general population or the refinery staff. No other regularly scheduled activities associated with the operations of the facility are planned for the site. 


\subsection{Historical Background}

For more than one hundred years the Czechowice Oil Refinery, formerly the Vacuum Oil Company, owned by the Standard Oil Company of New York, a United States based company, has been producing petroleum products for industrial and commercial applications. Many of the refinery's products are specialty items such as semi-synthetic motor oils, hydraulic oils, high temperature lubricants and waxes. The history of the refinery dates back to 1896 where the refinery processed approximately 35,000 metric tons of paraffinic crude oil a year in the production of vacuum oil. Over the next several decades the refinery's capacity steadily increased with production exceeding 500,000 metric tons per year. During the early 1930s, the addition of several new product lines and processes transformed the refinery into the largest petroleum processing facility in Poland. With the onset of World War II, the refinery became a military target of the Allied Forces. Due to its high production and strategic location, the Allies bombed the facility in August of 1943. While under German occupation during the war, the Germans rebuilt only part of the refinery, the major restoration was completed by the Poles shortly after the end of World War II and full scale production resumed in February, 1946 (Czechowice Oil Refinery, 1995).

Today, with the end of the cold war and more than 1,300 employees and production exceeding millions of tons per year, in a variety of product lines, the Czechowice Oil Refinery faces many new challenges. The move to a market driven economy and privatization of many State (government) owned industries brings with it new responsibilities, not only in fiscal and business management but also environmental stewardship and ownership. Many years of a production 
oriented philosophy have created environmental conditions which now present a potential risk to human health and the environment. The disposal practices for process wastes generated by the refining of crude oil have created conditions that are unacceptable under today's environmental standards. The use of unlined lagoons for process waste disposal was the industry norm for many years, not only in Poland but the United States as well. As late as the 1980s process waste lagoons were still in use in the United States. In Poland the practice still exists.

The Czechowice Oil Refinery, while still following traditional disposal practices, have undertaken new and bold initiatives to begin the environmental restoration of the refinery. In collaboration with the Institute for Ecology of Industrial Areas (IETU), located in Katowice, Poland and the United States, Department of Energy (DOE), a program for the demonstration of U.S. based technologies has been initiated with the Czechowice Oil Refinery as the industrial partner. This partnership not only includes the use of the refinery as the demonstration site, but also shared responsibilities in fiscal and engineering management of the project(s). Technical direction, guidance, project management and technology selection for the various phases of characterization, risk assessment and remediation are provided by Ames Laboratory, Florida State University and Westinghouse Savannah River Company, respectively.

The primary objectives for the program are to advance R\&D of EM technologies for use at DOE facilities in the United States, and to promote commercial development between U.S. and Polish/European environmental firms. U.S. and foreign cleanup efforts should be accelerated by performing advanced 
remediation activities on Upper Silesien test sites which have similar contamination problems as those at U.S. sites. The program will serve to address mutual objectives of both Poland and the U.S. related to environmental management. Included among these objectives are the demonstration of U.S. environmental technologies, development and commercialization, as well as topics related to these issues i.e., risk based management, technology transfer, communications and other forms of information dissemination (FSU, 1995). 
Test Plan

\subsection{Technical Need}

In 1991750 million tons of industrial wastes were deposited in the Upper Silesian Region of Poland, mostly in the Katowice Province. Annually, the industry of Katowice Province generates 60-70 million tons of waste. The Upper Silesian Region while rich in natural resources and densely populated, is considered to have very poor quality surface waters (the major source of potable water). Most rivers and streams in the region have very low flow with rates on the order of only a few $\mathrm{m}^{3} / \mathrm{s}$. As much as $70 \%$ of the volume of these rivers is made up of municipal sewage and industrial waste water. Some $62.6 \%$ of the $1,400 \mathrm{~km}$ of rivers in the region are out-of-class i.e. class 4 (waste water) or lower (IETU 1994). As sources of clean surface water steadily decline in Poland and throughout the world, our reliance on groundwater will undoubtedly: increase far into the next century. Therefore, with increasing urgency, ways have been sought to clean-up, i.e. remediate, petroleum and PAH contaminated soil and groundwater (Hazen 1991; Lombard et al., 1994). The Czechowice Oil Refinery demonstration will provide DOE-EM and the IETU with the opportunity to demonstrate and evaluate innovative, environmentally sound, and cost effective remediation techniques that can be used throughout the industrialized world to address clean-up of petroleum contaminated sites.

The basic concepts of this technology are expected to be applicable to other sites in the DOE complex having similar problems, especially low $\mathrm{pH}$. However, the particular process designs will be site specific (Lombard, 1990). The experience gained at the Polish demonstration will provide the basis for designs for other sites in Poland i.e., former Soviet military bases. 


\subsection{Technology Description}

Bioremediation is a process that mineralizes or transforms hydrocarbons (both xenobiotic and naturally occurring) introduced into the environment to less toxic or innocuous forms (Hazen, 1997). This technique can be applied either in situ or ex situ. There are a variety of bioremediation approaches, including biopiling, bioventing, biosparging and landfarming that can be applied in a large variety of ways. In as much as there are many approaches, so go the problems that accompany the application to a full-scale remedial effort. Such issues include biodegradation enhancement, nutrient and electron acceptor delivery and the integration of combinations of treatment technologies.

The microbial metabolism and fate of BTEX, TPH, PAHs and straight-chain and branched alkanes in the natural environment are areas of intense concern since many of these compounds and their break-down products display toxic and carcinogenic properties (Hazen, 1991). Many microorganisms including bacteria, fungi, yeasts and algae have the enzymatic capacity to completely mineralize petroleum hydrocarbons and utilize the carbon component to generate new biomass. For example, bacteria, under aerobic conditions oxidize PAHs to form dihydrodiols that are utilized in cell production (Atlas, 1984). An example of this bacterial oxidation pathway is the biotransformation of naphthalene to catechol (Fig. 2-1). Naphthalene and other arenes are among the most water soluble and potentially toxic compounds of petroleum and associated products. Indigenous microorganisms in the soil and groundwater can degrade large quantities of petroleum hydrocarbons if they are provided sufficient amounts of 
water, oxygen, and other limiting nutrients, usually nitrogen and phosphorus (Bartha and Bossert, 1984). Knowing these facts, it is easy to understand why the use of bioremediation as a remedial action is the best method for the treatment of PAHs at the Czechowice Oil Refinery site. Currently, Leaking Underground Storage Tank (LUST) Programs, in many states in the U.S., have selected bioremediation as the clean-up technology of choice. Use of this technology has shown that the 16 PAHs targeted by the USEPA in soil and sludge, in concentrations higher than $5,000 \mathrm{ppm}$ can be reduced by $95 \%$ in twenty weeks or less depending on the ambient conditions (Huis in't Veld et al., 1995). 
Figure 2-1 Bacterial Oxidation Pathway of Naphthalene to Catechol (Atlas 1984)<smiles>c1ccc2ccccc2c1</smiles>

Naphthalene

in the presence of:

Bacteria $+\mathrm{O}_{2}+$ Dioxygenase

$\downarrow$<smiles>Oc1ccc2ccccc2c1</smiles>

(+)-cis-1,2-Dihydroxy-1,2-dihydronaphthalene

$\downarrow$<smiles>Oc1ccc2ccccc2c1O</smiles>

1,2-Dihydroxy naph thalene

$\downarrow$

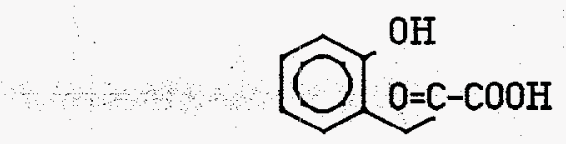

cis-o-Hydroxy benzal pyruvic acid

$\downarrow$<smiles>O=Cc1ccccc1O</smiles>

Salicylaldehyde

$\downarrow$<smiles>O=C(O)c1ccccc1O</smiles>

Salicylic acid<smiles>C1CC1</smiles><smiles>Oc1ccccc1O</smiles>

Meta Pathway

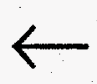

$\downarrow$

Catechol

i

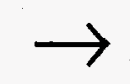

Ortho Pathway 


\subsection{Benefits}

Bioremediation technologies are based on biological destruction of the contaminants at the site. Therefore, risks normally associated with handling, transporting, and treating or storing contaminated residuals are lessened, if not avoided. In this sense there is a very significant reduction of risk (Hazen, 1997). Costs for in situ bioremediation of semi-volatile petroleum contamination i.e., polycyclic aromatic hydrocarbons (PAHs) are not well documented since this is an emerging technology. However, current in situ bioremediation technologies for other organics (such as gasoline) are nearly alwaýs less expensive than alternative technologies that provide physical destruction of the contaminants (and hence permanent remediation).

Bioremediation using techniques like landfarming, biopiling, bioventing, air/bio sparging and nutrient injection will lead to a significant reduction in the time required to complete the remediation because bioremediation provides a second simultaneous pathway for removal (destruction) of the PAHs. Furthermore, the stimulated indigenous microorganisms will gain access to the organic compounds in the soil and water matrices that may be very difficult or impossible to remove by soil vapor extraction or diffusion alone. The enzymes induced in the microorganisms oxidize a host of organic compounds, including toluene, benzene, and PAHs. Many previous laboratory studies have demonstrated the proof of this principle, thus a "cleaner" end point should be reached in less time (Hazen 1991; Hazen, 1997). 
Additionally, IETU will benefit by participating in cooperative projects that advance the $R \& D$ of Polish environmental technologies, demonstrate risk assessment methods and techniques related to soil contamination, which seriously effect the region, and engage in technology transfer, thus laying the foundation for future growth of the remediation and risk assessment fields, including education and skill transfer through cooperation.

\subsection{Alternatives}

A variety of alternative technologies to land disposal or storage in lagoons and basins of untreated petroleum contaminated wastes exist today. They include in situ/ex situ bioremediation, soil stabilization and solidification, soil vapor extraction, bioventing, excavation and subsequent soil washing and/or chémical treatment and incineration. In order to assure complete remediation, the technology chosen must be able to effectively treat the entire site and produce definable measures of remediation. Additionally, time to remediate, energy costs, required sampling (number of samples and required monitoring period after remediation), etc. must be considered. Several of these technologies have disadvantages that far outweigh the advantage of being used in lieu of ex situ bioremediation (biopiling).

For example, soil stabilization and solidification, although relatively low cost, generate a volume increase in material that requires additional handling and disposal. Because these processes only immobilize the contaminants and do not destroy them, possible limitations on future site use may also exist. 
Soil vapor extraction and bioventing are viable methods but they can require extensive site characterization and have very site specific applications. These methods also do not provide the level of control or the increased rates of biodegradation that a biopile would.

Soil washing (flushing) and chemical treatment can be used as a permanent treatment method but additional waste streams with potentially toxic byproducts are generated thus requiring further treatment, disposal and expense.

High and low temperature incineration is an effective method to destroy the $\mathrm{COCs}$ from this project. The performance of these systems is measured by the destruction and removal efficiency (DRE). Meeting the mandates of a high' temperature DRE of $99.9 \%$ can be costly, requiring the use of lärge amounts of supplemental fuel to support even the lowest operating parameters. Low temperature (catalytic) incineration is more applicable to petroleum contaminated material remediation but with both high and low temperature applications, permit conditions, contaminant concentrations, material volume, incinerator efficiency, catalyst cost, heating values of the waste, etc. all impact the final cost.

Due to the relatively high carbon content of the refinery waste $(\approx 60 \%)$, based on information provided by the refinery engineering staff, the refinery has elected to remove the bulk of the lagoon's material and sell it as an energy source for fuel in a cement kiln. A test burn, at the kiln, of the acidic refinery waste blended with a basic waste from a local chemical plant, was very successful (B. Jagosz, personal communication 1996). This is an excellent disposal method for 
the bulk removal of the COCs, that will provide the refinery with an additional source of revenue from what was once considered a waste, and the cement kiln with a relatively low cost, high BTU fuel supply for their production facility. Additionally, the refinery has also developed an extraction process. By steam heating the highly viscous material, found in the lagoon, they recover a usable product for burning in their own steam plant. These forms of energy conservation and usage are highly commendable and should be recognized as innovative in Poland's new market driven economy.

However, due to the shear volume of the lagoon's oil sludge wastes behind the protective clay dikes, oil and oily wastes have seeped under the clay dike and have contaminated an adjacent 5 ha. Results from coring has shown that this contamination is approximately two meters deep.

Biopiling: collects of all the contaminated soil; amends it to provide needed nutrients and favorable physical properties; provides complete containment of the contaminants through the use of a liner and cover material; provides optimal conditions for microbial activity through leachate recirculation and aeration; requires relatively low energy usages; and permits the reuse of the soil once remediation has been completed. In addition, the physicochemical characteristics of the newly identified material; $\mathrm{pH}(7.5 \pm 0.2)$, moisture content $(24.5 \% \pm 10)$, and petroleum content $(14.2 \% \pm 2)$ is superior to the originally selected lagoon material thus making it nearly ideal for a biopiling operation. Therefore biopiling is the only technology that completely degrades the contaminants (without creating a secondary waste stream) and permits the reuse of the (previously) contaminanted material without restriction. 


\subsection{Site Description and Area Maps}

The Czechowice Oil Refinery is located in the eastern portion of the city of Czechowice-Dziedzice which is located in the Katowice Voivodship in southern Poland (Fig. 2-2; 2-3). The history of the town dates back to the year 1337 . Some of the old hamlets like Grabowice, Zbijow or Swierkowice still exist. The Coat-of-Arms of the town of Czechowice-Dziedzice is symbolized by a cog-wheel, representing the towns technical education and mechanical industry. A blue background, which is the color of Silesia, highlights the crest. Yellow ears of corn are drawn on an orange hexagon representing the benzene molecule which is produced in the Silesian Refinery, the main industry in the town and the third largest refinery in Poland (Przedsiebiorstwo Geodezyjno-Kartograficzne 1996). A small city, with a population of approximately 30,000, Czechowice-Dziedzice is located approximately 45 kilometers from Katowice and 8 kilometers from Bielsko-Biala (Fig. 2-4). This region is one of the leading industrial areas of Poland.

2.6.1 Area Hydrogeology

The following section in based on information extracted from the draft Expedited Site Characterization Report of the Czechowice Oil Refinery by Ames Laboratory, Iowa State University, 1996.

Physiographically, the refinery is located in the Oswiecim Valley, which is part of the Fore-Carpathian Valleys. The average elevation is 250 meters (m) above 
Figure 2-2 Poland and Katowice/Bielsko-Biala Regional Map

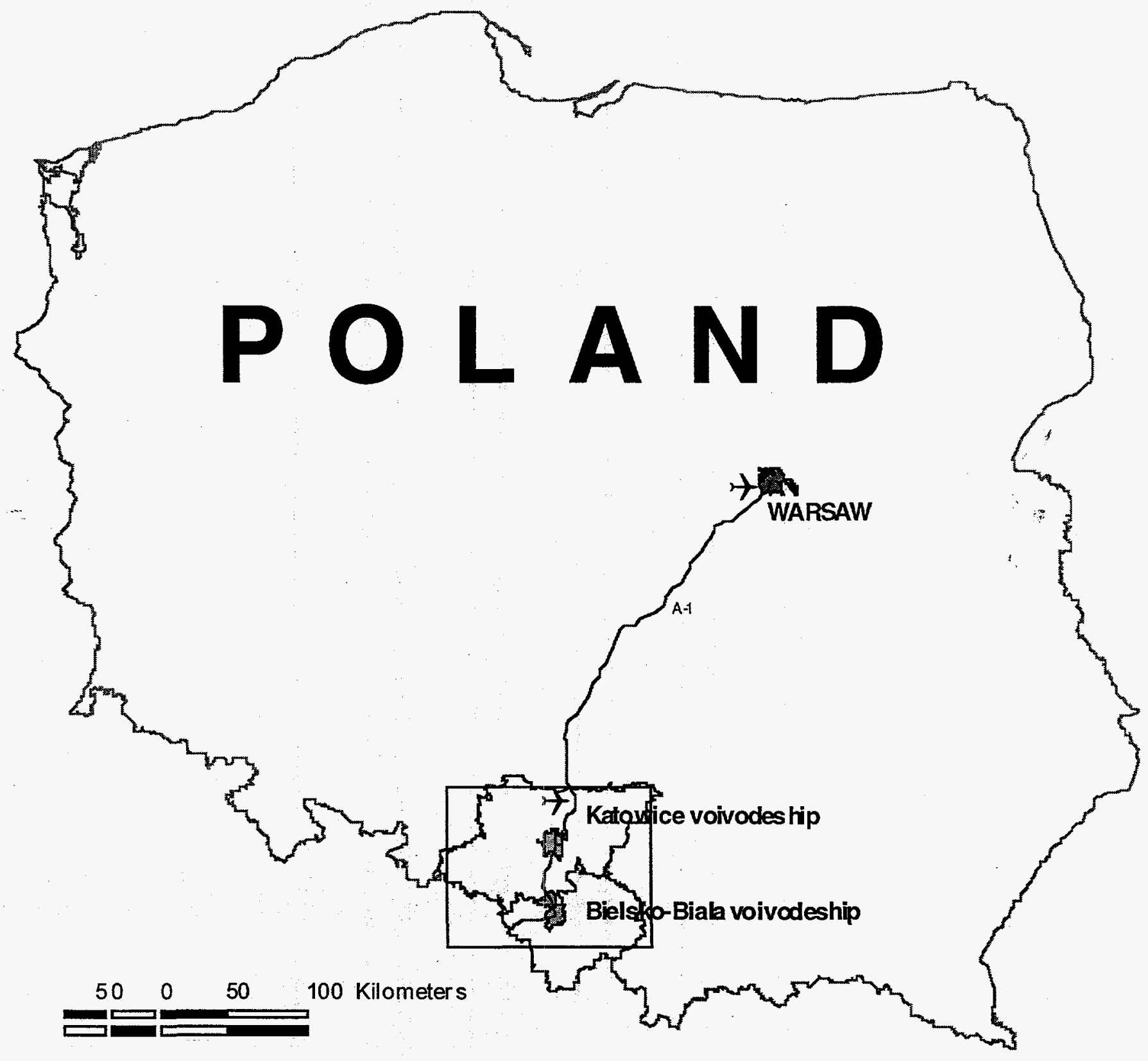


Figure 2-3 Katowice/Czechowice-Dziedzice Regional Map

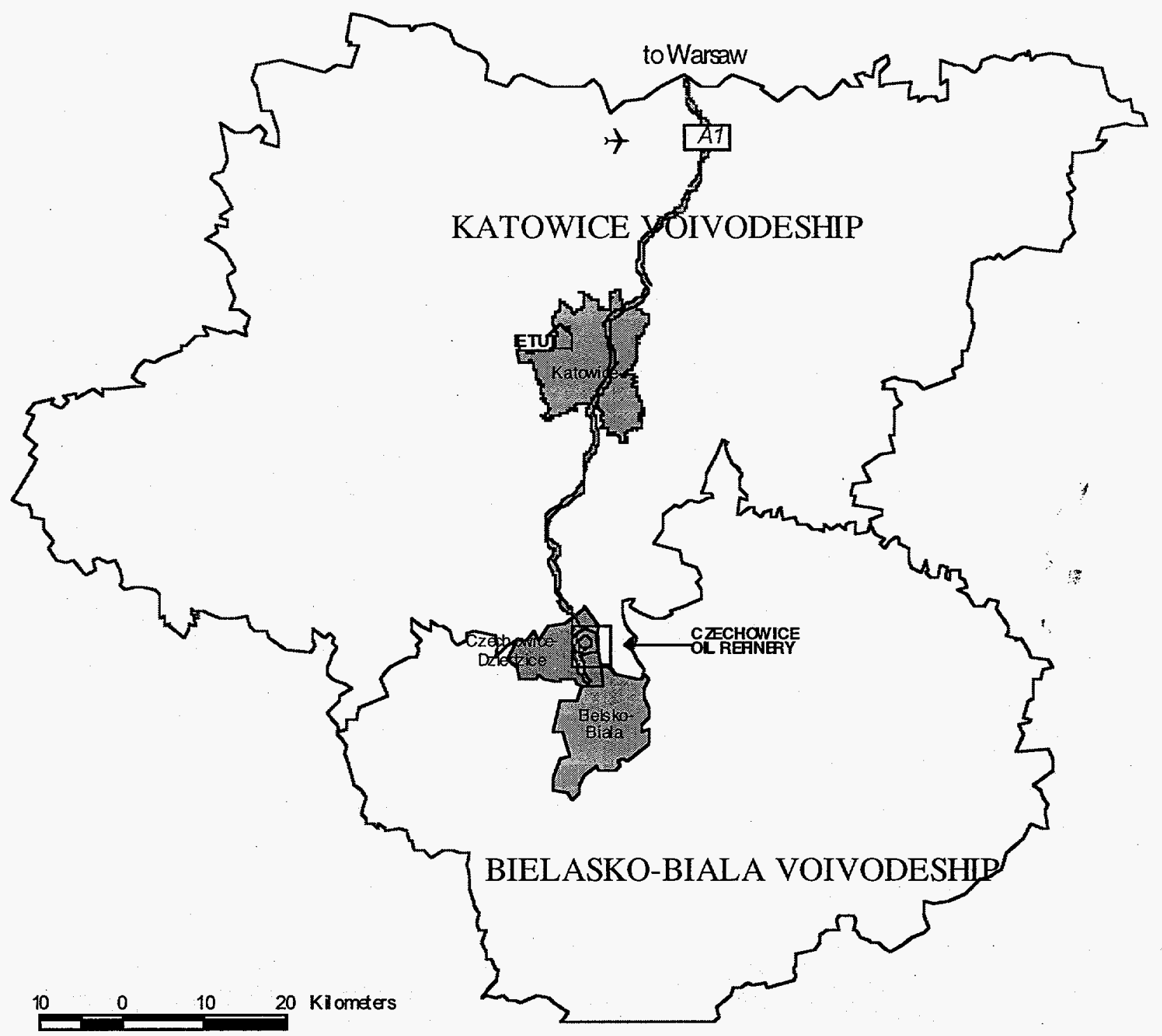


Czechowice Oil Refinery

Bioremediation Demonstration

Test Plan

Figure 2-4 Refinery Location Map
WSRC-RP-97-214

Revision: 0

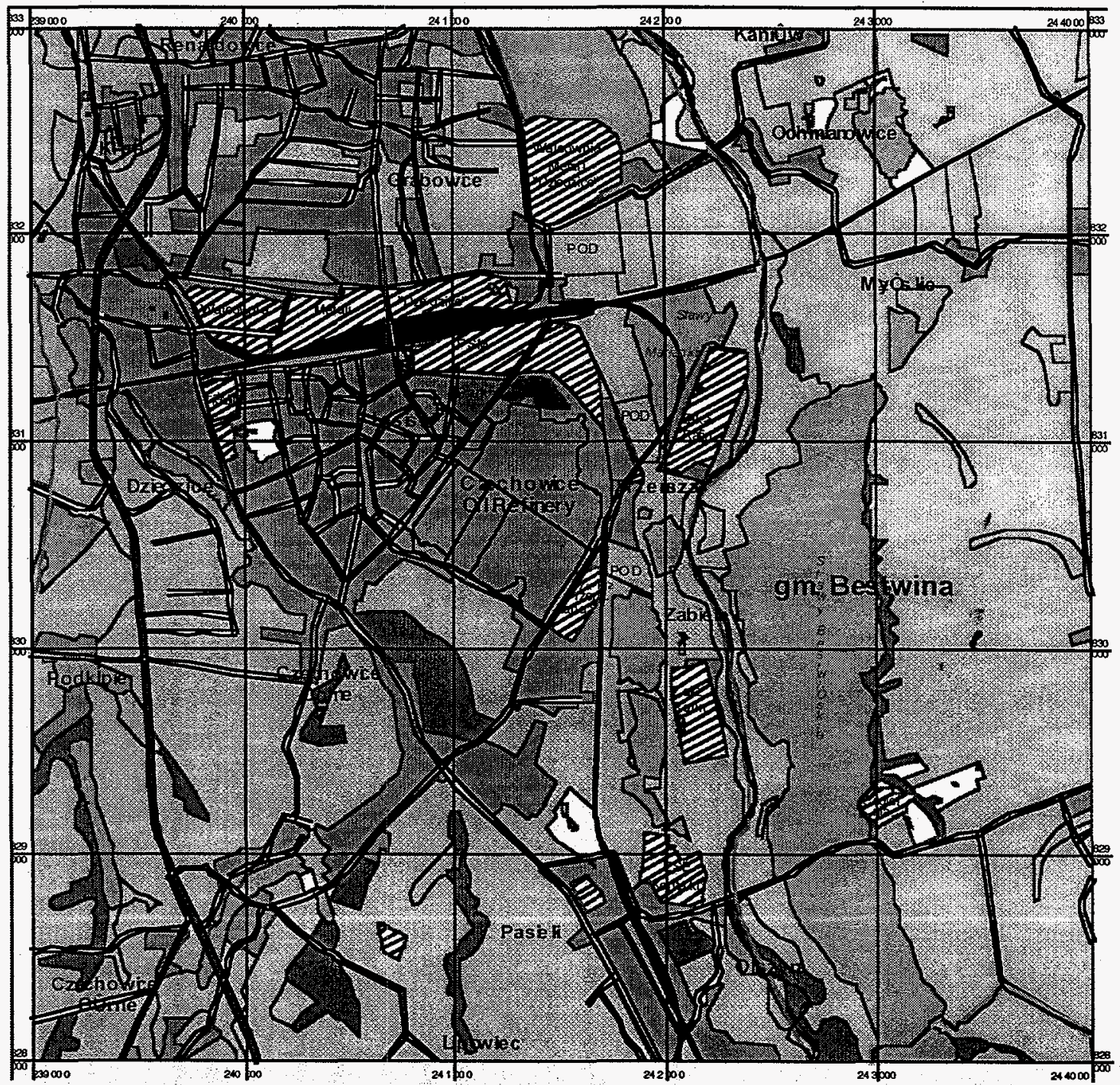


mean sea level. The hydrogeology of the area consists of surface water features including the Biala River which is located approximately $500 \mathrm{~m}$ East of the refinery and the Bestwine and Komorow Ponds approximately $1.5 \mathrm{~km}$ East of the river.

Brown and pedosolic soils are present on the surface. In the river valley, soils developed from alluvial deposits are present. Subsurface soils consist of glacial loam, clays, sands and silts. The glacial deposits are 1 to $15 \mathrm{~m}$ in depth. Glacial features occur below alluvial deposits. Gravels with sand and clay are 10 to $30 \mathrm{~m}$ in depth. These Quaternary deposits cover Tertiary age clays. The clays are up to $100 \mathrm{~m}$ in depth and cover a Carboniferous mudstone series with hard coal beds.

The surface clays and silts have a very low permeability. The estimated hydraulic conductivity of the sand and gravel deposits beneath the refinery is $0.005 \mathrm{~m} / \mathrm{sec}$, based on published information. Hydrogeologic information was collected from wells, which are used for pumping industrial water into the refinery. In 1995, the water table was measured monthly in nine wells. During the measurement period, the water table was about $12 \mathrm{~m}$ below ground surface (bgs), corresponding to a few meters below the top of the granular aquifer unit.

The thickness of the Quaternary sand and gravel aquifer varies between 8 to $30 \mathrm{~m}$. The direction of the groundwater flow is from $\mathrm{SW}$ to $\mathrm{NE}$, based on 
Czechowice Oil Refinery

Bioremediation Demonstration

Test Plan

Three piezometers were installed in late winter of 1995/1996 in positions near the targeted NW lagoon (Fig. 2-5). Table 2-1 shows various unit elevations with

depths referenced to mean sea level.
WSRC-RP-97-214,

Revision: 0

$$
\begin{aligned}
& \text { information from the refinery wells. Surface topographic data suggests a } \\
& \text { somewhat more easterly direction of flow. }
\end{aligned}
$$


Czechowice Oil Refinery

Bioremediation Demonstration

Test Plan
WSRC-RP-97-214

Revision: 0

Figure 2-5 Refinery Lagoons

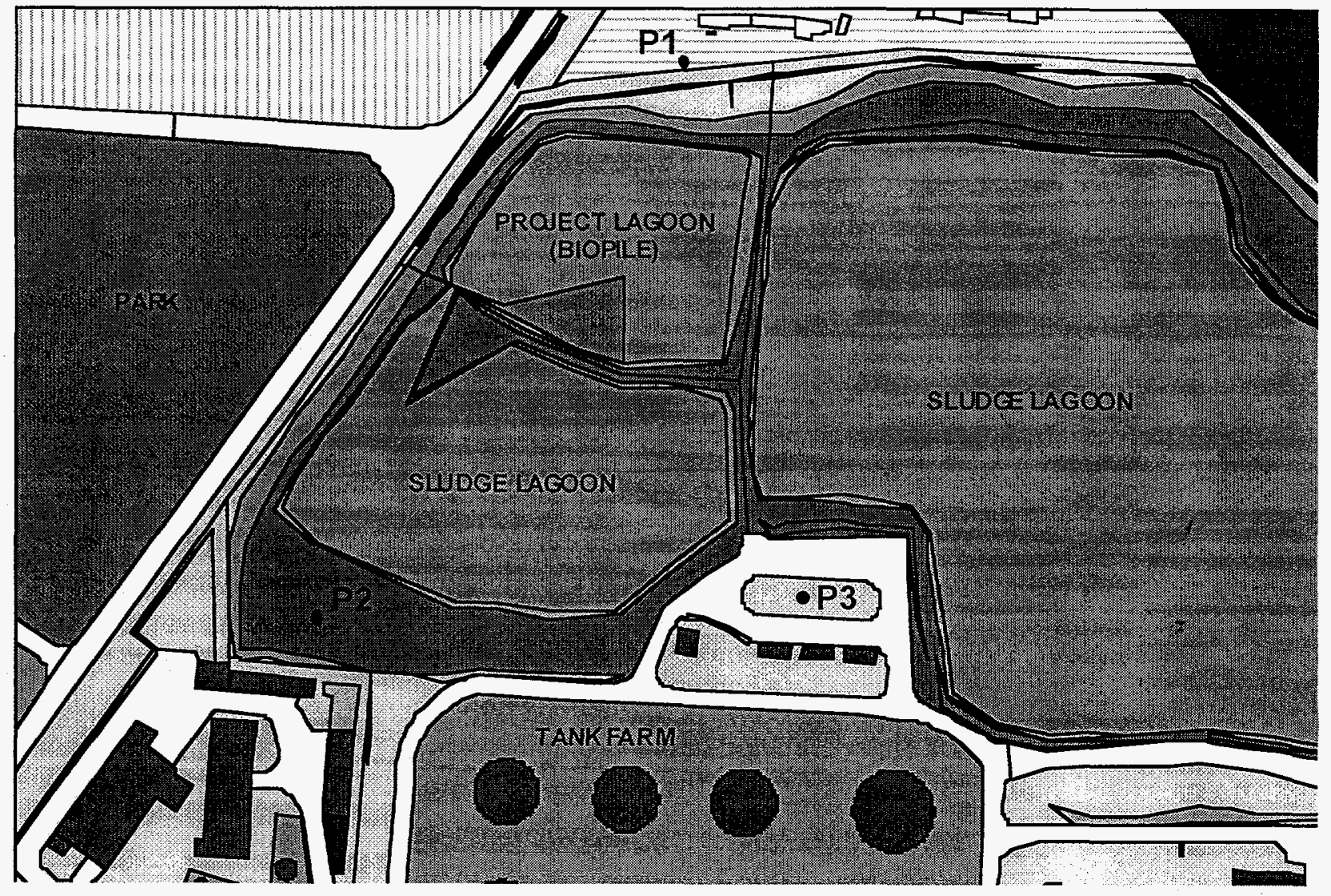


Table 2-1 Stratigraphic Data on Piezometers (all lengths in meters)

Surface

Elevation

P-1 261.0

P-2 263.2

P-3 263.5
Elevation to the Bottom of Unit

Fill

CL

GW

$\mathrm{CH}$

$$
261.0^{*}
$$

244.3

260.5

250.6

244.1

238.2

259.8

250.4

243.7

* Indicates no Fill

$\mathrm{CL}$ = fine grained clay of low to medium plasticity

$\mathrm{GW}=$ coarse grained gravel sand mixture

$\mathrm{CH}=$ fat clay or very fine high plasticity clay

From Table 2-1 it is clear that the depth above sea level to the top and bottom of aquifer unit (GW) is nearly the same indicating relatively flat subsurface strata. The aquifer unit is approximately 11 meters below the original ground surface (approximately $13 \mathrm{~m}$ below the top of the lagoon berms), and the aquifer is approximately $6.5 \mathrm{~m}$ thick in the vicinity of the lagoons. 
Test Plan

\section{TEST PLAN}

\subsection{Criteria for Success}

There are three primary criterion by which the overall success of this demonstration will be evaluated:

1. Evidence of biological destruction (biodegradation) of petroleum (PAH, TPH and BTEX) from the contaminated material. Since a major advantage of bioremediation is destruction, it is important and significant to demonstrate that biodegradation is occurring. The evidence is expected to come primarily from comparison of the biopile material and soils analysis taken before and after the waste is subjected to the treatment process (nutrient addition, aeration, $\mathrm{pH}$ adjustment and moisture control) to stimulate biodegradation.

2. Relatively simple and trouble-free operation. A critical assumption for the successful demonstration of the technology is that the system, as designed, will function with little or no down time and provide operating conditions that minimize fugitive air emissions and maximize biodegradation rates. The proposed project has no precedence in Poland and as such represents new technology for the country. However, since several other nations have demonstrated similar technologies, it represents a relative low risk and should have high public acceptance. The simplistic design contributes direct benefits associated with the ease of management and operation. A minimal staff will be required to operate the equipment, again adding to the low risk factor by limiting exposure to operations 
personnel.

3. Demonstrate the application of bioventing/biosparging as a viable process to degrade large molecular weight compounds (PAHs) by utilizing state-of-the-art monitoring equipment, analytical techniques and treatability studies to determine the rate and volume reduction in the starting concentrations of the contaminants. Deliverables include; 1) Training for IETU personnel in the use and application of monitoring equipment, 2) Bioremediation demonstration test plan, 3) Functional design criteria for the full-scale bioremediation demonstration, 4) Presentation of the project at Warsaw '96, and 5) writing a final report.

\subsection{Biopile Description}

This bioremediation demonstration project will focus mainly on the clean-up technique known as "biopiling". The biopile process is very similar to active bioventing, where air, as an oxygen source, and other amendments are forced through the vadose zone sediments either by vacuum extraction or by injection to stimulate the microbial oxidation of the hydrocarbons. As the name implies, biopiling is an ex situ process. The contaminated material is excavated and recombined or amended with other materials e.g., nutrients, sand, sawdust, compost or other similar bulking agents, as needed, to aide in permeability, and then placed in an engineered structure (configuration), to support or stimulate the biological reactions necessary to oxidize the hydrocarbons. Typically, this is a composting process with forced air via vacuum extraction, moisture control, nutrient addition and environmental monitoring, using thermocouple temperature probes, moisture probes and real time soil gas monitoring. 


\subsubsection{Biopile Design and Construction}

In this project, a biopile will be constructed utilizing waste materials (contaminated soil, litter and sludge). The pile will be constructed in the existing excavated lagoon as seen in DWG. POL-DJA-001; App. A, beginning with a dolomite base, approximately $1 \mathrm{ft}(30.48 \mathrm{~cm})$ deep as a leachate collector. A sump pump to recycle the leachate back to a holding lagoon, a vacuum extraction system, and a trickle system in the top of the pile will be installed to control moisture within the biopile.

The holding lagoon (DWG. POL-DJA-001; App. A), will be constructed within the existing lagoon and is designed to receive a supply of make-up water from the existing waste treatment facility at the refinery, as as the leachate collected from the pile. Due to the high concentration'. of bacteria in the make-up water $\left(>10^{8} / \mathrm{ml}\right)$, the lagoon water will also serve as a source of innoculum for the biopile. The holding lagoon will also have an air injection system installed to aid in mixing and oxygenation of the water supply for the biopile.

There will be a vacuum extraction system (VES) consisting of 2 in $(5 \mathrm{~cm}$ ) piping that will have an effective zone of influence to move .25 to .5 pore volumes of soil gas per day, installed directly above the leachate collection system. The VES will aid in pulling air through the pile to keep the environment aerobic. The VES will generate between 45 to $90 \mathrm{scfm} @ 7$ to 10 in $\mathrm{Hg}$ (1.26 to 2.52 cubic $\mathrm{m} / \mathrm{min} @ 177.8$ to $254 \mathrm{~mm} \mathrm{Hg}$ ) based on an estimated biopile size of 8,000 metric tons of contaminated material. The 
effluent air stream generated by the VES will be reinjected into the water supply of the holding lagoon, thus, the lagoon will not only act as a bioreactor to break down any contaminants found in the effluent water supply, but potentially as a biofilter to help control air emissions and eliminate odors as well. An additional biopile, compost filter or reinjection back into the existing pile would also provide a good form of air emissions control. Air flows will be monitored and adjusted to minimize emissions from the surface of the lagoon while maximizing the aeration.

As described by the USEPA (EPA/540/R-95/534a), one driving force behind the development of bioventing was the difficulty of delivering oxygen in situ. Many contaminants, especially petroleum hydrocarbons, are biodegradable in the presence of oxygen. Enhanced bioreclamation processes use water to carry oxygen or an alternative electron acceptor to the contaminated zone. This process was common, whether the contamination was present in the ground water or in the unsaturated zone. Media for adding oxygen to contaminated areas have included pureoxygen-sparged water, air-sparged water, hydrogen peroxide, and air.

In all cases where water is used, the solubility of oxygen is the limiting factor effecting mass transfer. At standard conditions, a maximum of 8 $\mathrm{mg} / \mathrm{L}$ to $10 \mathrm{mg} / \mathrm{L}$ of oxygen can be obtained in water when aerated. The stoichiometric equation 3.2.1 shown below is an example that can be used to calculate the quantity of water that must be delivered to provide sufficient oxygen for biodegradation. 
Eq. 3.2.1 $\mathrm{C}_{6} \mathrm{H}_{14}+9.5 \mathrm{O}_{2} \rightarrow 6 \mathrm{CO}_{2}+7 \mathrm{H}_{2} \mathrm{O}$

An example of the mass of water that must be delivered for hydrocarbon degradation to occur is shown below. Based on Equation 3.2.1, the stoichiometric molar ratio of hydrocarbon to oxygen is 1:9.5 or, to degrade 1 mole of hydrocarbon, 9.5 moles of oxygen must be consumed. On a mass basis:

$$
\frac{1 \text { mole }_{6} \mathrm{H}_{14}}{9.5 \text { moles }_{2}} \times \frac{1 \text { mole O}_{2}}{32 \mathrm{~g} \mathrm{O}_{2}} \times \frac{86 \mathrm{~g} \mathrm{C}_{6} \mathrm{H}_{14}}{1 \mathrm{~mole}_{6} \mathrm{H}_{14}}=\frac{86 \mathrm{~g} \mathrm{C}_{6} \mathrm{H}_{14}}{304 \mathrm{~g} \mathrm{O}_{2}}=\frac{1 \mathrm{~g} \mathrm{C}_{6} \mathrm{H}_{14}}{3.5 \mathrm{~g} \mathrm{O}_{2}}
$$

Given an average concentration of $9 \mathrm{mg} / \mathrm{L}$ of oxygen dissolved in water, the amount of air-saturated water that must be delivered to degrade $1 \mathrm{~g}$ of hydrocarbon is calculated as follows:

$$
\frac{3.5 \mathrm{~g} \mathrm{O}_{2} \text { required }}{\frac{9 \mathrm{mg} \mathrm{O}_{2}}{1 \mathrm{~L} \mathrm{H}_{2} \mathrm{O}} \times \frac{1 \mathrm{~g}}{1,000 \mathrm{mg}}}=\frac{390 \mathrm{~L} \mathrm{H}_{2} \mathrm{O}}{1 \mathrm{~g} \mathrm{C}_{6} \mathrm{H}_{14}}
$$

or, to degrade $1 \mathrm{lb}$ :

$$
\frac{390 \mathrm{~L} \mathrm{H}_{2} \mathrm{O}}{1 \mathrm{~g} \mathrm{C}_{6} \mathrm{H}_{14}} \times \frac{1,000 \mathrm{~g}}{2.2 \mathrm{lb}}=178,600 \mathrm{~L} \mathrm{H}_{2} \mathrm{O} / 1 \mathrm{lb} \mathrm{C} 6 \mathrm{H}_{14}
$$

Table 3-41 summarizes oxygen requirements based on the supplied source of oxygen. 
Table 3-1 Oxygen Requirements Based on Source

$\begin{array}{lcc}\text { Oxygen Form } & \begin{array}{c}\text { Oxygen } \\ \text { Concentration in } \mathbf{H}_{2} \mathrm{O}\end{array} & \begin{array}{c}\text { Volume to } \\ \text { Degrade } \mathbf{1} \text { lb } \\ \text { Hydrocarbon }\end{array} \\ \text { Air-saturated } \mathrm{H}_{2} \mathrm{O} & 8 \mathrm{mg} / \mathrm{L} \text { to } 10 \mathrm{mg} / \mathrm{L} & 180,000 \mathrm{~L} \\ \text { Oxygen-saturated } \mathrm{H}_{2} \mathrm{O} & 40 \mathrm{mg} / \mathrm{L} \text { to } 50 \mathrm{mg} / \mathrm{L} & 42,000 \mathrm{~L} \\ \text { Hydrogen peroxide } & \text { Up to } 500 \mathrm{mg} / \mathrm{L} & 6,100 \mathrm{~L} \\ \text { Air } & \text { NA }(21 \% \text { vol./vol. in air }) & 4,800 \mathrm{~L} \\ & & \\ \text { NA }=\text { not applicable. } & & \end{array}$

Based on current findings from the IETU treatibility study, and an understanding of the mass transfer limitations of air-saturated waters as an oxygen delivery system and the costs and safety concerns associated with pure oxygen generation, vacuum extraction combined with air-saturated water were selected for the biopile electron acceptor delivery system. Clearly, the goals established by the risk assessment for the clean-up criteria and the final end use of the site will be met with this process.

Above the vacuum lines the biopile will be constructed of alternating layers of a contaminated material mixture $(\approx 3 \mathrm{~m})$ and filter fabric. The composition of the mixture will be approximately $70 \%$ lagoon waste, $20 \%$ compost (some type of bulking agent, possibly sawdust) and 10\% dolomite as a $\mathrm{pH}$ amendment and a mixture stabilizer. A non-woven, needle punched geotextile soil stabilization fabric to support moisture distribution and prevent channeling of water through the pile will be placed between each lift of mixture. A more exact mixing ratio of the 
contaminant mixture will be provided upon completion of the column study for permeability being conducted by IETU.

In the top of the biopile approximately $1 \mathrm{ft}(20-30 \mathrm{~cm})$ below the surface, a trickle system for water will be installed to maintain soil moisture between $20-80 \%$ of the biopile's field capacity. The target range is $30-40 \%$. The water supply will come from the holding lagoon and will be returned back to the lagoon via the leachate collection system.

\subsubsection{System Performance}

Biodegradation of petroleum hydrocarbons in soil (petroleum land farming) has been used by the oil industry for more than 30 years as an efficient way to destroy oil sludges (Bartha and Bossert, 1984). Bý applying oil to the soil surface, adding fertilizer ( $P \& N$ ), water, and then tilling to aerate (oxygen), the soil microbes have been shown to completely degrade large quantities of oil. A demonstration of this technology using waste oil was done at the Savannah River Site near Central Shops in 1980 (Watts and Corey, 1982).

Until recently, the state-of-the-art approach to soil remediation was excavation and disposal at a secure landfill. Changes in liability concerns, costs, and regulatory constraints have decreased the popularity of excavation and disposal as a soil cleanup alternative. Landfill disposal of contaminated soil does not remove the future liability of its generator, who will be held jointly liable with the landfill operator for any future 
associated contamination.

Thus, on site permanent solutions must be sought whenever possible.

At this time, it has been estimated, based on previous work performed by WSRC and others, that the removal of BTEX will be between $90-99.9 \%$ with a reduction in TPH of $65-90 \%$ and $\mathrm{PAH}$ removal between $50-75 \%$. Sims (1986) reported $50-100 \%$ reduction of fossil fuels in soil after only 22 days. St. John and Sikes (1988) reported that a prepared bed system, complete with fugitive air emissions control, at a Texas oil field was able to reduce volatile organic carbon by $>99 \%$ after 94 days, with semivolatiles being reduced by more than $89 \%$. In California, Ross et al. (1988) reported that four acres of soil 15 in $(38 \mathrm{~cm})$ deep, contaminated with diesel and waste motor oils were decreased from $2,800 \mathrm{ppm}$ TPH to less than 380 ppm in only four weeks. He also reported that at another site owned by a heavy equipment manufacturer, $7,500 \mathrm{~m}^{3}$ were reduced to $<100 \mathrm{ppm}$ TPH after nine weeks and an additional $9,000 \mathrm{~m}^{3}$ with $180 \mathrm{ppm}$ TPH were reduced to $<10 \mathrm{ppm}$ after only five weeks. Another site in California had $600 \mathrm{~m}^{3}$ reduced from $1000 \mathrm{ppm}$ TPH to $<200 \mathrm{ppm}$ in 35 days. Molnaa and Grubbs (1989) report other sites in California where similar results were obtained, e.g., $2000 \mathrm{~m}^{3}$ with $2800 \mathrm{ppm}$ TPH were reduced to less than 38 ppm in 74 days, a truck stop where $15,000 \mathrm{~m}^{3}$ were reduced from 3000 ppm TPH to less than $30 \mathrm{ppm} \mathrm{TPH} \mathrm{in} 62$ days, and a site contaminated with lubricating oils where $25,000 \mathrm{~m}^{3}$ were reduced from $4800 \mathrm{ppm}$ down to $125 \mathrm{ppm}$ in 58 days. Based on the initial concentrations ( $>200,000$ 
$\mathrm{mg} / \mathrm{kg}$ TPH in litter) reported by Ulfig, et al. 1996, the rates of removal should range between 10 to $80 \mathrm{mg} / \mathrm{kg}$ of soil per day for TPH and could exceed $120 \mathrm{mg} / \mathrm{kg}$ of soil per day, based on similar work by Reisinger, et al. 1996. Reisinger experienced a $41 \%$ removal of TPH over the first two quarters (180 days) of biopile operations, based on respiration test data. Seasonal variations and other system parameters will also impact removal rates.

\subsubsection{Cost Analysis}

Cost analysis of this project (demonstration) is highly variable at this time. Based on in-kind contributions by the refinery, IETU and others for the procurement of materials, equipment and labor to support the construction, operations and sampling and analysis necessary to complete the project, costs could range from $\$ 600 \mathrm{k}$ to $\$ 850 \mathrm{k}$ USD. Again, keeping in mind that this project is a demonstration of a variety of technologies. Occasions may arise that will provide a "window of opportunity" for the development of new and unique technological applications that could effect the estimated cost of the project. Not with-standing the existing conditions at the project site, the cost and clean-up of the site could actually be less than first projected.

\subsection{Process Monitoring}

Monitoring of the system will be accomplished in a variety of ways. Soil gas piezometers will be installed in the biopile to monitor carbon dioxide $\left(\mathrm{CO}_{2}\right)$, 
oxygen $\left(\mathrm{O}_{2}\right)$, methane $\left(\mathrm{CH}_{4}\right)$, volatile organic hydrocarbons (VOCs) and semivolatile organic hydrocarbons (sVOCs). Water and soil samples will by analyzed for VOCs, sVOCs, polycyclic aromatic hydrocarbons (PAHs) nutrients, inorganics and microbiological activity. Water quality will be tested for $\mathrm{pH}$, dissolved oxygen (DO), specific conductance, temperature and other chemical and physical parameters like BOD and COD. The data gained from the monitoring program will be used to calculate the biodegradation rates for BTEX, PAH and total petroleum hydrocarbons (TPH). Respiration testing will be conducted to monitor $\mathrm{O}_{2}$ utilization during the remediation and helium tracer tests will be performed to monitor the air flow, distribution and hydraulic conductivity with respect to the permeability of the contaminant mixture within the biopile during vacuum extraction. This information will enable an appraisal to be done on the , remediation time necessary to meet the clean-up criteria set by the risk assessment.

\subsubsection{Monitoring Equipment}

The products and manufacturers listed in this document are meant as guidance for environmental managers and consulting engineers.

The Brüel \& Kjær (B\&K) Multi-gas Monitor, Type 1302 is a highly accurate, reliable and stable quantitative gas analyzer which is microprocessor controlled. Its measurement principle is based on the photoacoustic infrared detection method. In effect this means that the $\mathrm{B} \& \mathrm{~K} 1302$ can be used to measure almost any gas which absorbs infra-red light. The 1302s 
detection threshold is gas-dependent but typically in the $10^{-3} \mathrm{ppm}$ region (Brüel \& Kjær, 1996).

In this project the B\&K will serve a dual role. First, the instrument will be used for personnel occupational health and safety monitoring. Initial environmental sampling indicates the presence of benzene, a known human carcinogen. The instrument assigned to this project has been setup and calibrated for benzene monitoring. The second role the instrument will be used for is process monitoring of soil gases. The $B \& K$ is set-up to selectively measure the concentration of up to 5 component gases and water vapor in any air sample. For this project the instrument will monitor benzene, toluene, xylene(s) and naphthalene as well as $\mathrm{CO}_{2}$ and water vapor.

This instrument is available from Brüel \& Kjær, 2850 Nærum, Denmark, Telephone: +4542800500 . The cost of the unit with accessories is approximately $\$ 25,000.00$ USD.

The Landtec GEM-500 Gas Extraction Monitor is a highly reliable gas monitoring unit originally designed for the detection of landfill gases. Initially, when decomposable materials are placed in a landfill, the materials are placed there in an aerobic atmosphere. Through a natural biological process bacteria decompose the organic matter and in the process consume the oxygen creating an anaerobic environment. From this process, methane and carbon dioxide are produced. The Landtec GEM-500 is designed to detect $\mathrm{CH}_{4}, \mathrm{CO}_{2}$ and $\mathrm{O}_{2}$ concentrations in soil gas. Because the 
biopile is designed to be an aerobic system the GEM-500 will be employed to monitor the production of $\mathrm{CO}_{2}$ and the depletion of $\mathrm{O}_{2}$ and in this case, the lack of the presence of methane indicating aerobic conditions exist in the subsurface of the biopile. The lack of $\mathrm{CH}_{4}$ production and the presence of $\mathrm{CO}_{2}$ indicate the system is providing an adequate $\mathrm{O}_{2}$ supply for the aerobic biological processes to take place. The instrument's detection ranges are $0-100 \%$ for methane, $0-50 \%$ for carbon dioxide and $0-25 \%$ for oxygen with a resolution of 0.1 for all gases.

The GEM-500 is manufactured by Landfill Control Technologies, 6055 E. Washington Blvd., Commerce, CA 94110, USA. The cost of the unit with accessories is approximately $\$ 8,000.00$ USD.

In a former acid refining process used for the manufacture of motor oil, large quantities of sulfuric acid $\left(\mathrm{H}_{2} \mathrm{SO}_{4}\right)$ were used in the processing operation. The $\mathrm{H}_{2} \mathrm{SO}_{4}$ was disposed of in the waste lagoon creating a potential health hazard when the materials are mixed or disturbed. In order to monitor the airborne concentrations of $\mathrm{H}_{2} \mathrm{SO}_{4}$ during the construction and operation of the biopile system a Single Point Monitor (SPM) manufactured by Zellweger Analytics will be deployed. The SPM combines the well proven Chemcassette ${ }^{\mathrm{TM}}$ Detection System and microprocessor control to achieve optimum detection speed, accuracy, and specificity. It responds quickly to hazardous releases, yet ignores other commonly used chemicals. The SPM is easy to operate and maintain. The SPM can quickly be set up for monitoring, and routine maintenance requires less that three hours annually. 
The SPM is manufactured by Zellweger Analytics, Inc., 405 Barclay Blvd., P.O. Box 1405, Lincolnshire, IL 60069-9842. Telephone; 800-323-2000. The cost of the unit with accessories is approximately $\$ 6,000.00$ USD. 


\section{SAMPLING AND ANALYSIS}

Soils will be collected during the the Expedited Site Characterization (ESC), the initial phase of the remediation demonstration and again for post demonstration characterization for analysis of VOCs, microbial counts, physical parameters, and miscellaneous parameters. Because of the inherently high variability of hydrocarbons in soils, the number of samples required to produce a meaningful result is prohibitive until contamination levels approach 90 percent to 99 percent of the cleanup criteria. The amount of soil sampling conducted at a site has a tremendous impact on the cost of the project. Minimizing soil sampling makes a remediation effort much more cost-effective. With biopile systems, in situ respiration testing can indicate when the site is clean and, therefore, when to collect final soil samples.

Periodic soil gas monitoring will be conducted to ensure that the biopile system is well oxygenated. Initially, soil gas should be monitored weekly until the site becomes fully aerated. Once full aeration is achieved, system operation can be optimized. After this initial period, soil gas monitoring normally is conducted bimonthly for the first year, during the warmest and coldest months, and monthly thereafter. If conducting an in situ respiration test during different seasons is not possible, then it should be conducted during the same seasons as the initial test. Because of the relative simplicity of most biopile systems, frequent soil gas monitoring rarely is necessary to ensure proper operation.

In situ respiration testing should be used as a preliminary indicator for site closure. A good indication that the site is remediated and that final soil sampling 
can be conducted is an in situ respiration rate in the contaminated area similar to that in the uncontaminated area. In situ respiration testing to determine remediation success is economically significant because soil sampling is not relied upon as the sole indicator of site remediation, thus eliminating the high cost of intermediate soil sampling.

\subsection{Soil Sampling Protocol}

Soils for VOC analysis will be collected using a modified syringe tube and plunger and placed in a $20-40 \mathrm{ml}$ headspace vial: Five milliliters of solution, comprised of $10 \mathrm{~g}$ of sodium sulfate and $0.3 \mathrm{ml}$ of phosphoric acid $(0.15 \%)$ in $200 \mathrm{ml}$ of distilled water, will be added to the vial. The vials will then be sealed with crimped aluminum rings over Teflon-lined septa. Samples will be placed in a cooler on ice and managed according to the hold times as seen in Table 4-1. Prior to sample analysis, samples will be weighed to determine the mass of the sample.

Core specimens for microbial analysis will be obtained directly from the soil sampler. Cores will be sectioned with sterile spatulas and the outermost layer scraped off using a sterile scoopula. The sample will then be placed in a sterile Whirl-Pak bag and transported to the laboratory on ice for immediate analysis according to this test plan. Laboratory analyses will be performed by personnel at the IETU laboratory. 
Table 4-1 Soil Sample Holding Times

\begin{tabular}{|l|c|}
\hline \multicolumn{1}{|c|}{ CONTAMINANT } & HOLDING TIME \\
\hline \hline $\begin{array}{l}\text { Benzene, Toluene, Ethylbenzene, } \\
\text { Xylenes }\end{array}$ & $\begin{array}{c}\text { Analyze as soon as possible } \\
\text { (maximum 14 days) }\end{array}$ \\
\hline $\begin{array}{l}\text { Total Petroleum Hydrocarbon } \\
\text { (low to medium bp fuels) }\end{array}$ & $\begin{array}{c}\text { Analyze as soon as possible } \\
\text { (maximum 14 days) }\end{array}$ \\
\hline $\begin{array}{l}\text { Total Petroleum Hydrocarbon } \\
\text { (high bp fuels) }\end{array}$ & $\begin{array}{c}\text { Extract within 14 days } \\
\text { Analyze within 40 days }\end{array}$ \\
\hline $\begin{array}{l}\text { Polycyclic Aromatic } \\
\text { Hydrocarbons (PAH) } \\
\text { (including naphthalene) }\end{array}$ & $\begin{array}{c}\text { Extract within 14 days } \\
\text { Analyze within 40 days }\end{array}$ \\
\hline Mercury & 28 days1 \\
\hline Metals (except mercury) & 6 months 1 \\
\hline \hline
\end{tabular}

Source: SCDHEC, 1992

1.) Soil samples must be at least $200 \mathrm{~g}$ and usually require no preservation other than storing at $4^{\circ} \mathrm{C}$ until analyzed.

\subsection{Soil Gas Sampling Protocols}

The following protocol will be utilized for sampling soil gases. First, a magnehelic gage or other measuring device will be attached to the quick connect fitting for measurement of pressure. Second, a high volume pump approximately 5 liters per minute $(1 / \mathrm{min})$ will be attached to the quick connect and the well gas will be evacuated until oxygen readings have stabilized indicating that one is monitoring soil gas rather than well gases. Third, The Landtec GEM-500 or equal will be attached and measurements of $\mathrm{O}_{2}, \mathrm{CO}_{2}$, and $\mathrm{CH}_{4}$ will be taken. Fourth, the Brüel \& Kjær multi-gas 
monitor will be used for the detection and analysis of VOCs including benzene, toluene and xylene(s) and the sVOC naphthalene after which the evacuation pump will be used for the collection of samples in 1-liter Tedlar bags and/or SUMMA canisters. The samples shall be placed in a cooler on ice and transported to the IETU as soon as possible. Laboratory and field analyses as seen in Table 4-2 will be performed by personnel at the IETU laboratory.

\subsection{Groundwater Sampling Protocols}

A sampling pump or bailer will be used to collect groundwater samples from the groundwater saturated zone piezometers according to SRTC direction. Water will be filtered in the field, if required, with 45 micron mesh filters. Water levels will be monitored with an electric water-level indicator. Field water parameters including dissolved oxygen, oxidationreduction potential (ORP), $\mathrm{pH}$, specific conductivity, and temperature, will be monitored using the Hydrolab Surveyor (Hydrolab Inc., Houston, TX) or approved equal in the field. The Hydrolab Surveyor probes used for estimation of dissolved oxygen and $\mathrm{pH}$ will be calibrated prior to each use. All other probes on the Hydrolab will be calibrated monthly.

Laboratory and field analyses will be performed by personnel at the IETU laboratory. Analytical methods (VOCs and methane) for groundwater samples will be analyzed as noted for soils. Total VOC and carbon dioxide groundwater samples will be prepared and analyzed as follows.

Groundwater samples will be acidified in a serum bottle with a crimp seal 
septa. Thirty milliliters of groundwater will be added to an amber serum bottle, capped and crimped in the field and held on ice until analyzed. One milliliter of concentrated hydrochloric acid will be added to serum bottles with a syringe, allowed to equilibrate, and then $2.5 \mathrm{ml}$ of headspace will be injected into a GC with a thermal conductivity detector.(TCD). Standards will be made with sodium bicarbonate solutions (EPA Method 524.2).

\section{Table 4-2}

Frequency and Parameters for Soil, Water and Soil Gas Samples

\begin{tabular}{|c|c|c|c|c|c|c|}
\hline & Initial & & onthly & Weekly & Final & \\
\hline \multicolumn{7}{|l|}{ Organics } \\
\hline TPH & $Y$ & as & needed & $\mathrm{N}$ & $\mathrm{Y}$ & : \\
\hline BTEX & Y & as & needed & $\mathrm{N}$ & $\mathrm{Y}$ & \\
\hline PAH & $\mathrm{Y}$ & as & needed & $\mathrm{N}$ & $Y$ & \\
\hline \multicolumn{7}{|c|}{ Inorganics } \\
\hline $\mathrm{N}$ & Y & & $\mathrm{Y}$ & - & - & \\
\hline $\mathrm{P}$ & $\mathrm{Y}$ & & $\mathrm{Y}$ & - & - & \\
\hline Moisture & $\mathrm{Y}$ & & $\mathrm{Y}$ & Y & - & \\
\hline $\mathrm{pH}$ & $\mathrm{Y}$ & & $\mathrm{Y}$ & $\mathrm{Y}$ & - & \\
\hline Metals & $\mathrm{Y}$ & & - & - & - & \\
\hline Microbes & $Y$ & & $\mathrm{Y}$ & - & - & \\
\hline
\end{tabular}

The assays will be performed by the IETU with EPA approved methods. Total Organic Carbon (TOC) will be determined by the ultraviolet oxidation method (EPA 415.1). Samples will be acidified and stored at $4^{\circ} \mathrm{C}$ prior to analysis. 
Soluble reactive phosphate concentrations will be measured by the ascorbic acid colorimetric determination method (EPA 365.2). Total Phosphorus will be determined by the persulfate digestion and ascorbic acid colorimetric determination (EPA 365.2). thermal conductivity detector (TCD which includes free-ammonia plus organic nitrogen will be determined colorimetrically following digestion, distillation and Nesslerization method (EPA 351.3). Ammonia as distilled ammonia nitrogen will be determined colorimetrically following distillation and Nesslerization method (EPA 350.2). Nitrate, Nitrite, and Sulfate will be determined by the ion chromatography method (EPA 300.0). Alkalinity will be done by the $\mathrm{pH} 4.5$ titrametric method (EPA 625/410).

\subsection{Analytical Procedures}

The EPA 8000 series analytical procedures found in Table 4.4 will be used in the analysis of soil samples. The use of these methods is now nearly universal in public and private sector laboratories. Each of these methods has an associated list of target compounds for which it was specifically developed and evaluated. These methods use gas chromatography (GC) and mass spectrometers (MS) or a combination of both GC/MS techniques to detect organic compounds. These instruments are well known for their excellent sensitivity and selectivity for specific target compounds.

Detection of complex hydrocarbon mixtures is best achieved using a GC with a flame ionization detector (GC-FID). GC-FID analysis provides a more adequate representation of the degree of hydrocarbon contamination. EPA Method 418.1 does not provide jnformation on the type of hydrocarbon contamination and the 
low boiling point components are easily lost. This method will only be used for screening purposes and final disposal will be governed by GC analysis.

The procedures outlined in Table 4-3 list different methodologies for the low to medium boiling point hydrocarbons (gasoline) and the high boiling point hydrocarbons (diesel motor fuels and light heating fuels). A purge and trap or head space is preferred for the more volatile contaminants whereas the high boiling point contaminants are to be analyzed using a GC-FID. The gas chromatographic analysis is equivalent to the well known "California Method" for testing TPHs for the Underground Storage Tank Program. For highly contaminated samples a waste dilution technique may be used but this must be documented with the analytical results. 
Test Plan

\section{Table 4-3}

Dissolved Hydrocarbons and Corresponding Methods of Analysis

\begin{tabular}{|c|c|c|}
\hline Analytical Group & Constituent & Analytical method \\
\hline $\begin{array}{l}\text { Gasoline } \\
\text { (all motor gasoline } \\
\text { and Gasohol) }\end{array}$ & $\begin{array}{l}1,2 \text {-dichloroethane } \\
\text { benzene } \\
\text { toluene } \\
\text { ethylbenzene } \\
\text { total xylenes } \\
\text { total volatile organic } \\
\text { aromatics }\end{array}$ & $\begin{array}{l}\text { EPA Method } 8010 \\
\text { EPA Method } 8020 \\
\text { EPA Method } 8020 \\
\text { EPA Method } 8020 \\
\text { EPA Method } 8020 \\
\text { EPA Method } 8020 \\
\text { EPA Method } 5030 \\
\text { GC-FID California }\end{array}$ \\
\hline $\begin{array}{l}\text { Middle distillates } \\
\text { (kerosene, diesel fuel } \\
\text { and light fuel oils) }\end{array}$ & $\begin{array}{l}\text { naphthalene and } \\
\text { other semivolatiles } \\
\text { BTEX }\end{array}$ & $\begin{array}{l}\text { EPA method } 8270 \\
\text { EPA method } 8020 \\
\text { Approved test kits } 1 \\
\text { (screening only) }\end{array}$ \\
\hline$\because$ & $n$-propylbenzene & $\begin{array}{l}\text { EPA method } 8020 \\
\text { EPA Method } 3550 \\
\text { GC-FID California } 1\end{array}$ \\
\hline \multirow[t]{2}{*}{ Other or unknown } & $\begin{array}{l}\text { Priority pollutant } \\
\text { metals }\end{array}$ & $\begin{array}{l}\text { Toxicity } \\
\text { Characteristic } \\
\text { Leaching Procedure }\end{array}$ \\
\hline & $\begin{array}{l}\text { Total Petroleum } \\
\text { Hydrocarbons }\end{array}$ & $\begin{array}{l}\text { EPA Method } 9071 \\
\text { with silica gel clean-up } \\
\text { EPA method } 418.1^{2} \\
\text { (screening only) }\end{array}$ \\
\hline
\end{tabular}

1. California Method: Leaking Underground Fuel Tanks Field Manual. Guidelines for Site Assessment, Clean-up and Underground Storage Tank Closure. State of California, May 1988.

2. Method 418.1 is no longer a recommended method by SCDHEC for final soil disposal determinations. However, this analytical method is acceptable for a preliminary screening process. 


\subsection{Microbiological Procedures}

Three microbiological analyses will be done on a monthly basis. The soil samples from the biopile will be collected and processed on the same day the sampling was done. The first test will give total direct cell counts in the soil, utilizing an acridine orange stain for bacterial nucleic acids. This will provide a total bacterial cell count, expressed in cells per gram dry weight. The second analysis to be performed is a viable count, this will give the total number of organisms that can be cultured on an oligitrophic media. This number is expressed in colony forming units per gram dry weight. The third analysis is an enrichment for TPH. Bacteria will be grown on a minimal salts media with trace metals and TPH vapors as the only carbon source.

\subsubsection{Acridine Orange Direct Counts (AODC)}

AODC will provide a direct estimate of the total number of bacteria in the environment, regardless of ability to grow on any media that might be used. Samples are preserved in phosphate buffered formalin. Samples (1 to 3 grams) are extracted three times with a non-ionic homogenizing detergent to remove bacteria from the sediment particles. Homogenates are cleared by low speed centrifugation and the supernatants pooled. Ten microliters of supernatant is spotted onto each well of a toxoplasmosis microscope slide, stained with $0.01 \%$ acridine orange, then rinsed with distilled water. The number of cells stained with acridine orange are counted by epifluorescence microscopy. The number of cells per sample is normalized by dividing by the dry weight of the sediment. Counts are 
reported as cells per gram (Sinclair and Ghiorse, 1989).

\subsubsection{Aerobic Heterotrophic Plate Count}

This method will provide an estimate of the total number of viable aerobic and facultatively anaerobic bacteria in the groundwater. Low and high nutrient concentrations of a medium will be used to indicate differences in bacteria adapted to oligotrophic and eutrophic conditions. Sediment samples (1 to 3 grams) are weighed directly into $15 \mathrm{ml}$ conical centrifuge tubes containing $9 \mathrm{ml}$ of pyrophosphate buffer. Subsequent serial dilutions are made in phosphate buffered saline. $0.1 \mathrm{ml}$ of each appropriate dilution was inoculated onto a corresponding plate of appropriate medium. For this study, $1 \%$ peptone-trypticase-yeast extractglucose (PTYG) is used (Balkwill, 1989). Plates are incubated at room temperature for at least two weeks prior to counting. Bacterial colonies are counted with the aid of low power magnification. Counts are normalized to sediment dry weights and reported as colony forming units (CFU) per gram.

\subsubsection{TPH Enrichment}

This method will provide an estimate of the total number of viable aerobic and facultatively anaerobic bacteria capable of living in an enriched TPH soil. Successful bioremediation of TPH can also be measured in terms of increased microbial activity, increased biomass; particularly biomass which contains TPH degrading enzymes, increased biomass capable of consuming 
TPH as evidence of stimulation by treatments. Minimal salts media (Fogel et al., 1986) will be used. The plates will be incubated in an enclosed environment with TPH vapors available to the bacteria as a source of carbon for metabolism. This count will also be in colony forming units per gram dry weight. As petroleum will be the only carbon source available, this will be a count of TPH degraders only. Biometer flask measurements will also be taken as another source for the detection of carbon utilization by the TPH degraders.

\section{HEALTH AND SAFETY}

The chemical hazards and health risks associated with this project have been evaluated through the risk assessment process. Based on the risk assessment a Health and Safety Plan (HASP) has been prepared. The HASP can be seen in Appendix C. As a minimum, to reduce the possibility of exposure, hand and foot protection in the form of work gloves (rubber gloves during sampling) and boots with shoe covers should be worn while working in the designated exclusion zone. The site Health and Safety Officer will provide daily guidance on dress-out requirements necessary to perform the assigned tasks.

\subsection{Other Safety Information.}

Other sources of safety information include: NIOSH Pocket Guide to Chemical Hazards, publication No. 90-117, Federal Motor Carrier Safety Regulations Pocketbook, and WSRC Safety Guidelines for Subcontractors. 


\subsection{Quality Assurance/Quality Control}

All activities at the Czechowice Oil Refinery that are under the direction of WSRC personnel are governed by WSRC Quality Assurance Program as outlined in WSRC Management Policies, WSRC-1-01 MP 4.2. Site specific Quality Assurance Procedures are documented and controlled by the Czechowice Oil Refinery and the IETU as required. Additionally, any quality control inspection activities required to perform the tasks of this Test Plan shall by provided by the engineering staff of the Czechowice Oil Refinery. Additional field inspection support shall be provided by the IETU and WSRC as necessary.

\section{$5.2 \quad$ Security}

WSRC security requirements and procedures are documented in the WSRC Security Manual (7Q). These procedures are as required by Federal Laws and applicable DOE Orders, eg. DOE Order 5631.1A. These documents shall be in effect for WSRC employees.

\section{Patents}

The Office of Patent Counsel, DOE, prepared a Preliminary Patentability Search Report for the Prepared Bed Bioreactor design and the following patent references listed in Table 6.0 have been issued. Due to the similar nature of the project, the following patents are referenced. 
Czechowice Oil Refinery

Bioremediation Demonstration

Test Plan
WSRC-RP-97-214

Revision: 0

Table 6-1 Related Patent References

\begin{tabular}{|c||c||c|c|}
\hline PATENT & DATE & INVENTOR & SEARCH CLASS \\
\hline \hline $5,134,078$ & $07 / 92$ & Sieksmeyer, et al. & $432 / 262$ \\
\hline $5,128,262$ & $07 / 92$ & Lindoerfer, et al. & $435 / 262$ XR \\
\hline $4,962,034$ & $10 / 90$ & Khan & $435 / 262$ \\
\hline $4,871,673$ & $10 / 89$ & Rehm, et al. & $435 / 262$ \\
\hline $4,678,582$ & $07 / 87$ & Lavigne & $435 / 262$ XR \\
\hline $4,584,102$ & $04 / 89$ & Bogart, et.al & $405 / 128$ XR \\
\hline $4,447,541$ & $05 / 84$ & Peterson & $435 / 264$ \\
\hline \hline
\end{tabular}




\section{References}

Ames Laboratory. 1996. Report on the Results of the Expedited Site Characterization Demonstration at the Czechowice Refinery.

Atlas, R. M. 1984. Petroleum Microbiology. Macmillan Publishers, New York, NY.

Balkwill, D. L. 1989. Numbers, diversity, and morphological characteristics of aerobic, chemoheterotrophic bacteria in deep subsurface sediments from a site in South Carolina. Geomicrobiol. J. 7:33-52.

Bartha, R., and I. Bossert. 1984. Treatment and Disposal of Petroleum Refinery Wastes. In: R. M. Atlas (ed.), Petroleum Microbiology. Macmillan Publishers, New York, NY.

Brüel \& Kjær. 1996. Operating Manual for the Model 1302. Brüel \& Kjær, 2850 Nærum, Denmark.

Czechowice Oil Refinery, 1995. Public relations and historical information brochure. Czechowice-Dziedzice, Poland.

ECOVA. 1989. Solid Phase Bioremediation. ECOVA Corporation, Redmond, WA.

FSU. 1995. Program Plan for the United States Department of Energy and Institute for Ecology of Industrial Areas Partnership. Ed.,J. M. Kuperberg. Institute for Central and Eastern European Cooperative Environmental Research. Florida State University, Tallahassee, Florida.

Fogel, M. M., A. R. Taddeo, and S. Fogel. 1986. Biodegradation of chlorinated ethenes by a methane-utilizing mixed culture. Appl. Environ. Microbiol. $51: 720-724$.

Hazen, T. C. 1991. Test Plan for In Situ Bioremediation Demonstration of the Savannah River Integrated Demonstration Project, DOE/OTD TTP No.: SR 0566-01. Technical Report WSRC-RD-91-23. 82 pp. WSRC Information Services, Aiken, SC. 
Huis in't Veld, M. G. A., J. Werners, J. J. van Veen and H. J. Doddema. 1995. Biological PAH Degradation in Dredged Sludges, pp. 17-22. In: Bioremediation of Recalcitrant Organics, R. E. Hinchee (ed). In Situ and OnSite Bioreclamation, The Third International Symposium. San Diego, CA.

IETU. 1994. Institute for Ecology of Industrial Areas Annual Report. Katowice, Poland.

IETU. 1996. GIS Mapping Department. Institute for Ecology of Industrial Areas. Katowice, Poland.

Jagosz, B.1995. Personal communication. Chief Engineer, Czechowice Oil Refinery. Czechowice-Dziedzice, Poland.

Laczny, M. J. 1983. A Model of Groundwater Contamination from a Power Station Solid Waste Landfill. Institute for Environmental Protection. Katowice, Poland. ISBN 83-85-002-32-4.

Landfill Control Technologies. 1996. GEM-500 Operation Manual. Landf̣ill Control Technologies, 6055 E. Washington Blvd., Commerce, CA 94110, USA.

Lombard, K. H. 1994. Test Plan for A Petroleum Contaminated Soil Bioremediation Facility. Technical Report WSRC-TR-94-0179. Westinghouse Savannah River Company, Aiken, SC.

Lombard, K. H., J. Borthen, and T. C. Hazen. 1994. Design and Configuration Management of System Control Components for In Situ Methanotrophic Bioremediation of Groundwater and Sediment Contaminated with Chlorinated Hydrocarbons, pp. 81-96. In: Air Sparging for Site Remediation, R. E. Hinchee (ed). In Situ and On-Site Bioreclamation, The Second International Symposium. San Diego, CA.

Molnaa, B. A., and R. B. Grubbs. 1989. Bioremediation of Petroleum Contaminated Soils Using a Microbial Consortia as Inoculum. In: E. J. Calabrese \& P. T. Kostecki (eds.), Petroleum Contaminated Soils, vol. 2. Lewis Publishers, Chelsea, MI.

Preslo, L. M., Leis, W. M., and Pavlick, R. 1990. In: Petroleum Contaminated Soils, Vol. 2, p. 111. (Kostecki, P. T., and Calabrese, E. J., Eds.). Lewis Publishers, 
Test Plan

Chelsea, MI.

Przedsiebiorstwo Geodezyjno-Kartograficzne. 1996. Local map with historical description of the region. Katowice, Poland.

Reisinger, H. J., S. A. Mountain, G. Andreotti, G. DiLuise, A. Porto, A. Hullman, V. Owens, D. Arlotti, and J. Godfrey. in press. Bioremediation of a Major Inland Oil Spill Using a Comprehensive Integrated Approach. Proceedings: Third International Symposium and Exhibition on Environmental Contamination in Central and Eastern Europe. September, 1996.

Ross, D., T. P. Marziarz, and A. L. Bourquin. 1988. Bioremediation of Hazardous Waste Sites in the USA: Case histories. In: Superfund '88, Proc. 9th National. Conference. Hazardous Materials Control Research Institute, Silver Spring, MD.

Sims, R. C. 1986. Loading Rates and Frequencies for Land Treatment Systems. In: R. C. Loehr and J. F. Malina, Jr., (eds.) Land Treatment: A Hazardous Waste Management Alternative. Water Resources Symposium No. 13, Center for Research in Water Resources, The University of Texas at Austin, Austin, TX.

Sinclair, J. L., and W. C. Ghiorse. 1989. Distribution of aerobic bacteria, protozoa, algae, and fungi in deep subsurface sediments. Geomicrobiol. J. 7:15-32.

South Carolina Department of Health and Environmental Control. 1992. Petroleum Hydrocarbon Analytical Methodology for Ground Water and Soil Assessment. Laboratory Certification Section, P.O. Box 72, State Park, South Carolina 29147.

St. John, W. D., and D. J. Sikes. 1988. Complex Industrial Waste Sites. In: G. S. Omenn (ed.), Environmental biotechnology. Reducing Risks from Environmental Chemical through Biotechnology. Plenum Press, New York, NY.

Ulfig, K., G. Plaza, T. C. Hazen, C. B. Fliermans, M. M. Franck, and K. H. Lombard. in press. Bioremediation Treatability and Feasibility Studies at a Polish Petroleum Refinery. Proceedings: Third International Symposium and Exhibition on Environmental Contamination in Central and Eastern Europe. 
September, 1996.

U.S. Department of Health and Human Services. 1990. NIOSH Pocket Guide to Chemical Hazards. Public Health Service. Centers for Disease Control. National Institute for Occupational Safety and Health. Superintendent of Documents, U.S. Government Printing Office, Washington D.C. 20402.

U.S. Department of Transportation (USDOT). 1989. Federal Motor Carrier Safety Regulations Pocketbook. J. J. Keller and Associates, Inc., Pub. Neenah, Washington 54957-0368.

U.S. Environmental Protection Agency (USEPA). 1995. Manual: Bioventing Principles and Practice. Vol 1 and 2. Office of Research and Development Washington, DC 20460.

U.S. Environmental Protection Agency (USEPA). 1985. Compilation of Air Pollutant Emission Factors. AP-42, Fourth Edition. Office of Air Quality, Research Triangle Park, NC 27711.

U.S. Environmental Protection Agency (USEPA). 1986. Test Methods for Evaluating Solid Wastes, Physical/Chemical Methods. SW-846, 3rd edition. Superintendent of Documents, U.S. Government Printing Office, Washington D.C. 20402.

U.S. Environmental Protection Agency (USEPA). 1987. Industrial Source Complex (ISC) User's Guide; Second Edition (Revised). EPA-450/2-78027R. Office of Air Quality, Research Triangle Park, NC 27711.

U.S. Environmental Protection Agency (USEPA). 1988. A Workbook of Screening Techniques for Assessing Impacts of Toxic Air Pollutants. EPA-450/4-88009. Office of Air Quality, Research Triangle Park, NC 27711.

Vanderlaan, M., Stanker, L. H., and Watkins, B. E. 1990. In: Immunoassays for Trace Chemical Analysis, p. 2. (Vanderlaan, M., Stanker, L. H., Watkins, B. E. and Roberts, D. W., Eds.) Washington, D.C., American Chemical Society.

Watts, J. R., and J. C. Corey. 1982. Land Application Studies of Industrial Waste Oils. Environ. Pollution (Series A). 28:165-175. 
- Czechowice Oil Refinery

WSRC-RP-97-214

Bioremediation Demonstration

Revision: 0

Test Plan

Westinghouse Savannah River Company. Safety Guidelines for Subcontractors. Pocket handbook. Issued through SRS Safety Department. 
Czechowice Oil Refinery

Bioremediation Demonstration

Test Plan
WSRC-RP-97-214,

Revision: 0

\section{Appendix A}

\section{List of Acronyms and Abbreviations}




\section{List of Acronyms and Abbreviations}

\begin{tabular}{ll} 
APR & Air Purifying Respirator \\
AODC & Acridine Orange Direct Counts \\
B\&K & Brüel \& Kjær \\
BETX & Benzene, Ethyl Benzene, Toluene and Xylenes \\
bgs & below ground surface \\
b p & Boiling Point \\
CFU & Colony Forming Units \\
CH & Fat clay or very fine high plasticity clay \\
C & Fine grained clay of low to medium plasticity \\
COC & Contaminants Of Concern \\
COR & Czechowice Oil Refinery \\
DOE & United States Department of Energy \\
DRE & Destruction and Removal Efficiency \\
ESC & Expedited Site Characterization \\
FID & Flame Ionization Detector \\
FTL & Field Team Leader \\
FSU & Florida State University \\
CC & Gas Chromatography \\
GPR & Ground Penetrating Radar \\
GW & Coarse grained gravel sand mixture \\
HASP & Health and Safety Plan \\
IETU & Institute for Ecology of Industrial Areas \\
ISCST & Industrial Source Complex /Screening Techniques \\
LEL & Lower Explosive Limit \\
LUST & Leaking Underground Storage Tank \\
MEP & Ministry for Environmental Protection (Poland) \\
MWSP & Ministry for Welfare and Social Policy (Poland) \\
NIOSH & National Institute of Occupational Health and Safety (USA) \\
OSHA & Occupational Safety and Health Act (USA) \\
ORP & Oxidation-Reduction Potential \\
PAH & Polycyclic Aromatic Hydrocarbon \\
PID & Plasma Ionization Detector \\
PCA & Pollution Control Act \\
PTYG & 1\% Peptone-Trypticase-Yeast extract-Glucose \\
RCRA & Resource Conservation and Recovery Act \\
SCBA & Self Contained Breathing Apparatus \\
& \multicolumn{1}{|c}{} \\
& \\
&
\end{tabular}


Czechowice Oil

Bioremediation

Test Plan
Refinery

Demonstration
WSRC-RP-97-214,

Revision: 0

SCDHEC South Carolina Department of Health and Environmental Control SDWA Safe Drinking Water Act

SPM Single Point Monitor

SRS Savannah River Site

SRTC Savannah River Technology Center

SSO Site Safety Officer

TCD Thermal Conductivity Detector

TCLP Toxicity Characteristic Leaching Procedure

TOC Total Organic Carbon

TPH Total Petroleum Hydrocarbons

TPM Total Particulate Matter

TWA Time Weighted Average

USEPA U.S. Environmental Protection Agency

VES Vacuum Extraction System

VOC Volatile Organic Hydrocarbon

sVOC Semi-Volatile Organic Hydrocarbon

WSRC Westinghouse Savannah River Company 
"Czechowice Oil Refinery Bioremediation Demonstration

Test Plan

\section{Appendix B}

\section{Conceptual Biopile Design}

WSRC-RP-97-214

Revision: 0 


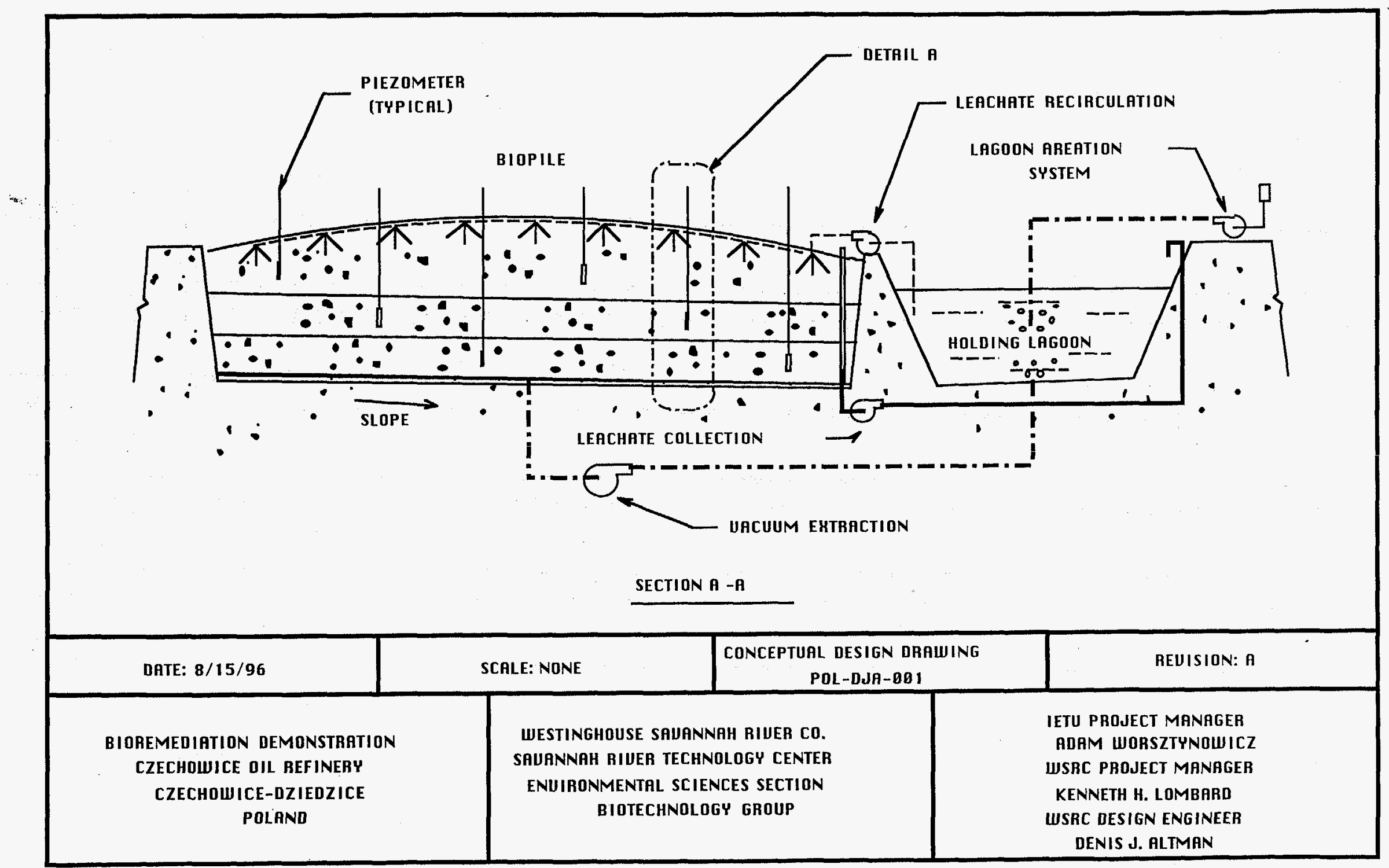




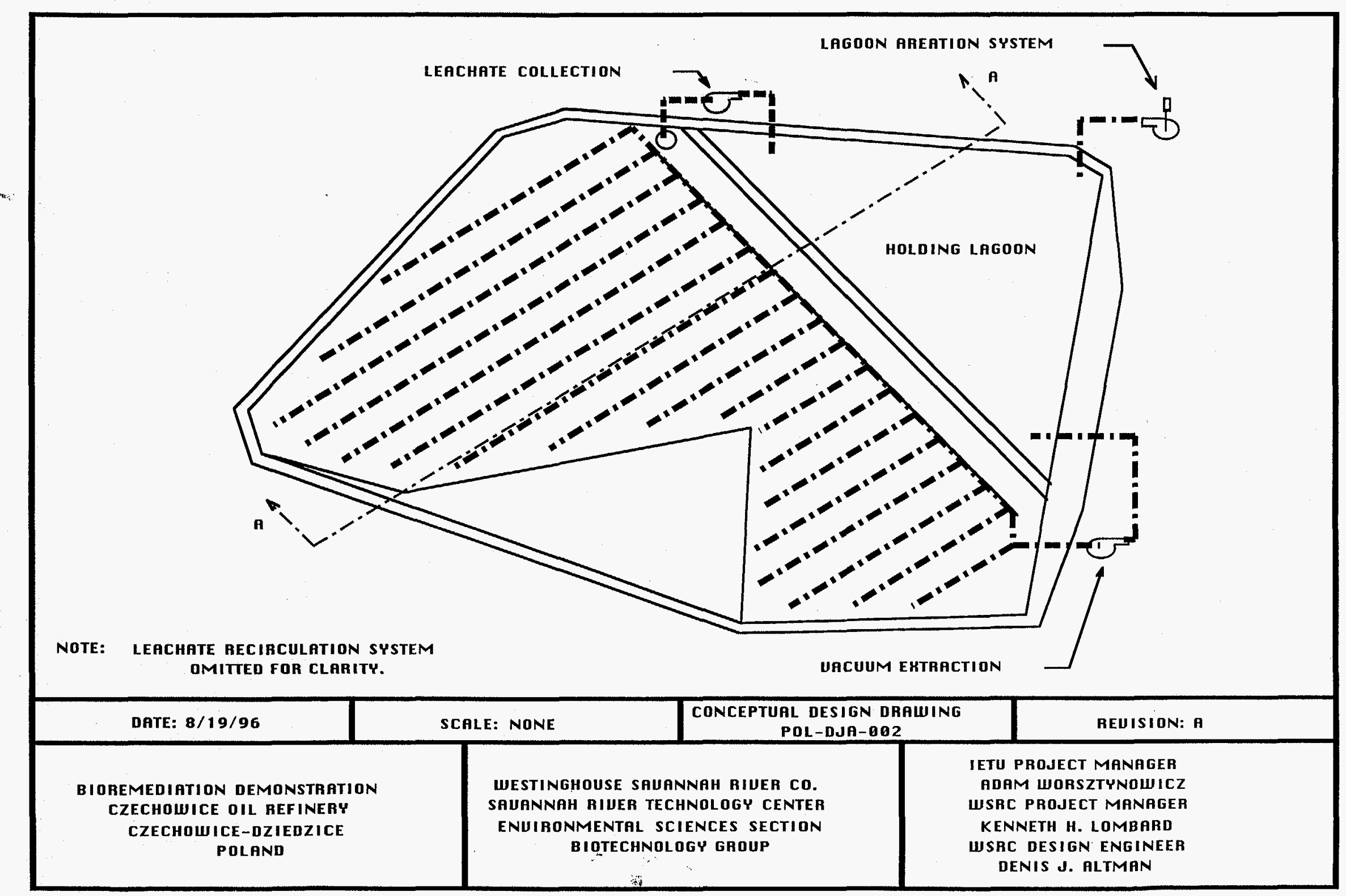




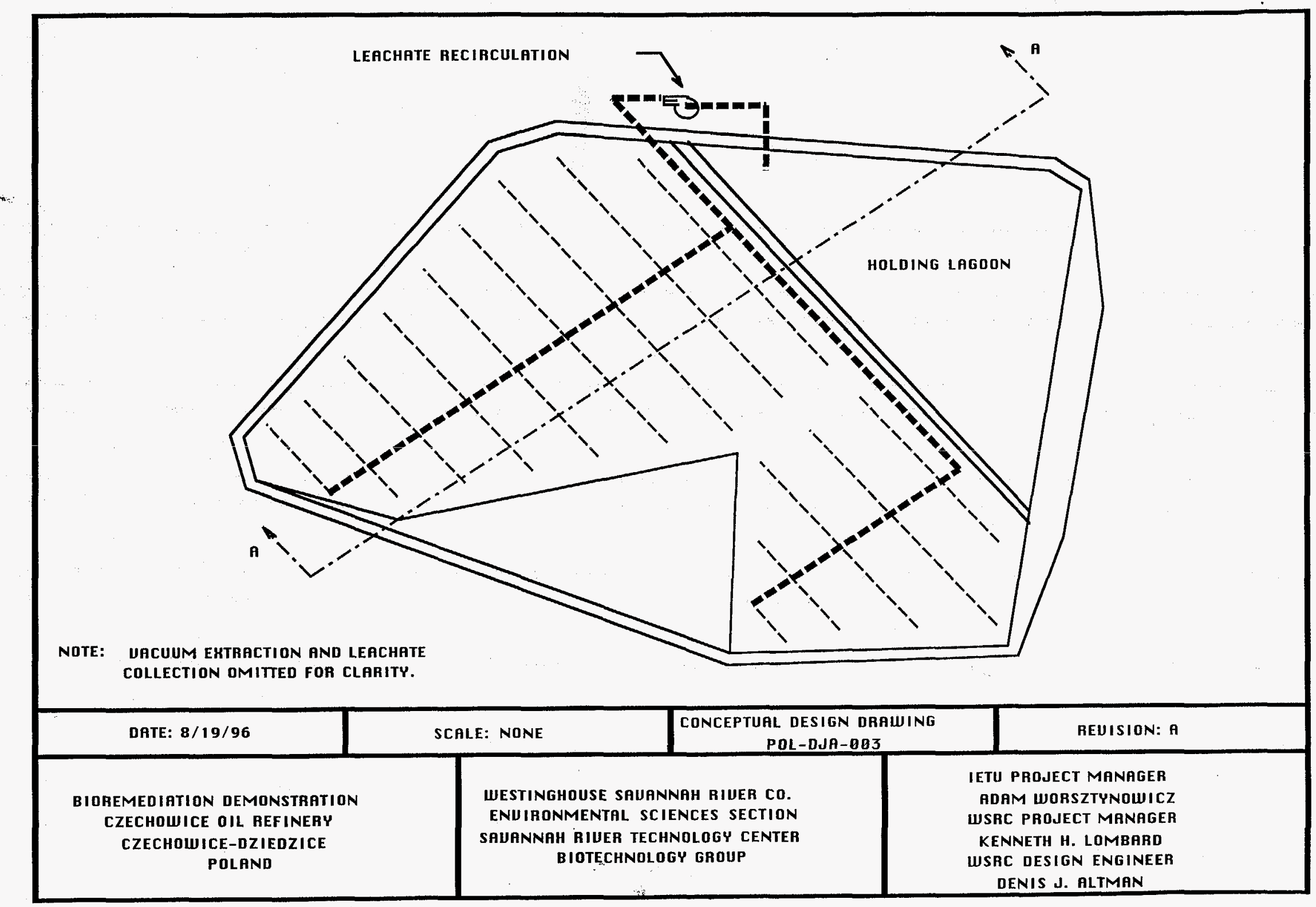




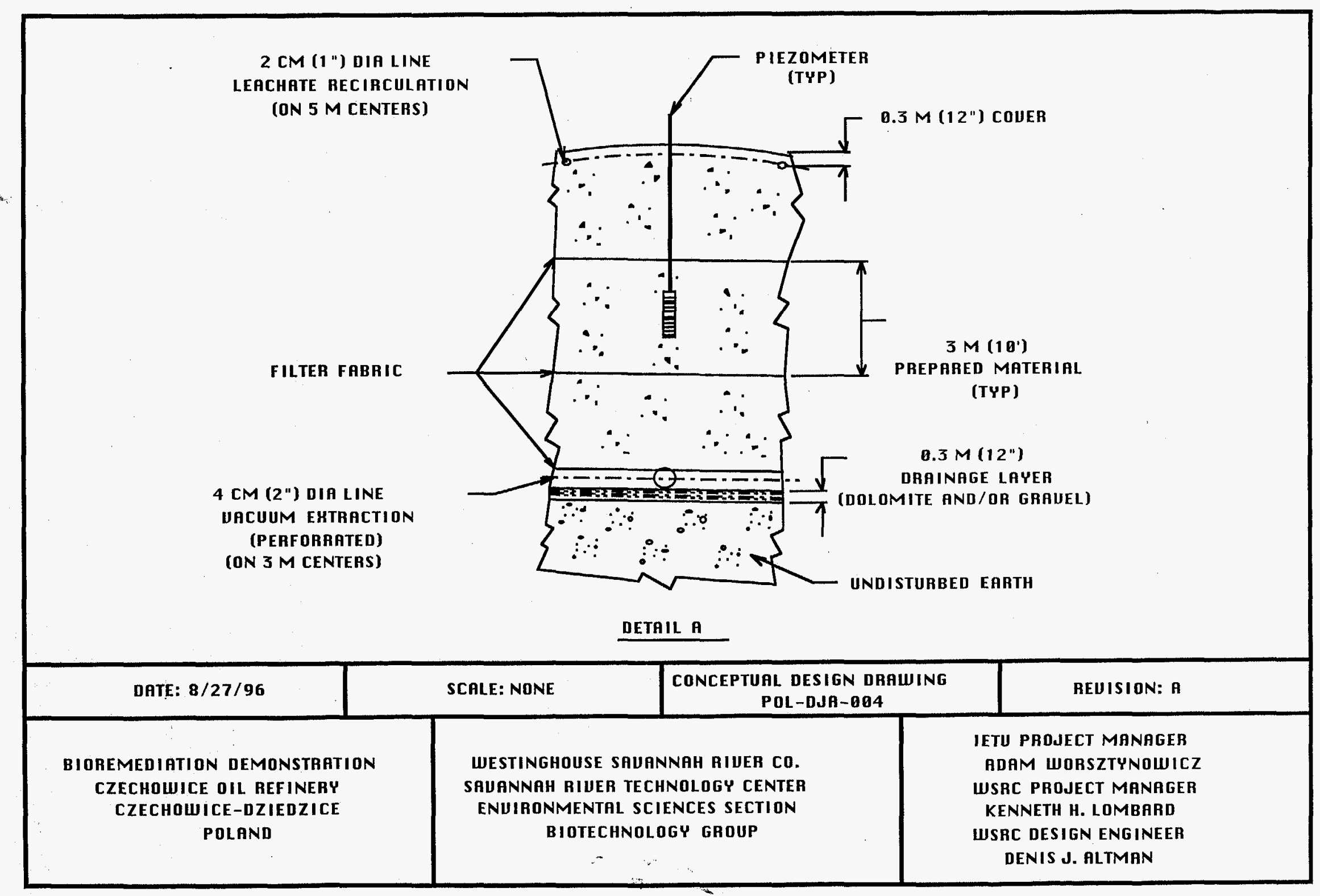


Czechowice Oil Refinery

Bioremediation Demonstration

Test Plan

Appendix $\mathrm{C}$

Health and Safety Plan
WSRC-RP-97-214 ,

Revision: 0 


\title{
HEALTH AND SAFETY PLAN
}

\author{
The Czechowice Oil Refinery \\ Bioremediation Demonstration \\ of a Process Waste Lagoon
}

Czechowice-Dziedzice, Poland

WESTINGHOUSE SAVANNAH RIVER COMPANY

SAVANNAH RIVER SITE

Aiken, South Carolina 29808

Prepared for the U.S. Department of Energy under Contract No. DE-AC09-89R180035 
II. SITE OVERVIEW

$\begin{array}{ll}\text { II.1 Site Selection } & 1\end{array}$

II.2 Site History and Description $\quad 2$

II.3 Site Geography and Local Land Use $\quad 2$

III. SCOPE OF WORK

III.1 Planned Site Activities and Dates - Bioremediation Demonstration 3

$\begin{array}{ll}\text { III.2 Number of People On site } & 3\end{array}$

$\begin{array}{ll}\text { III.3 Number of Days to Complete Work . } & 3\end{array}$

IV. WASTE CHARACTERISTICS $\quad 4$

$\begin{array}{lc}\text { IV.1 Chemical Hazards } & 5\end{array}$

IV.2 Physical Hazards $\quad 6$

IV.3 Hazards Posed by Site Activities : $\quad 6$

IV.4 Unusual Hazards $\quad 6$

IV.5 Overall Hazard Level $\quad$ : 6

$\begin{array}{ll}\text { V. PROCEDURES } & 6\end{array}$

$\begin{array}{lc}\text { V.1 Roles and Responsibilities } & 6\end{array}$

$\begin{array}{ll}\text { V.2 Training Requirements } & 7\end{array}$

$\begin{array}{ll}\text { V.3 Level of Protection } & 7\end{array}$

$\begin{array}{ll}\text { V.4 Action Levels } & 9\end{array}$

$\begin{array}{ll}\text { V.5 Monitoring Requirements } & 10\end{array}$

V.6 Site Organization and Control $\quad 10$

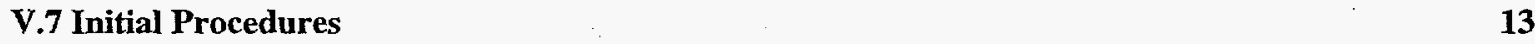

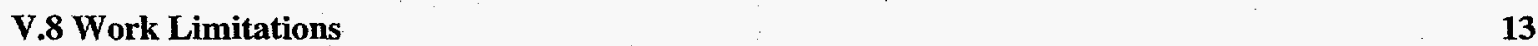

$\begin{array}{ll}\text { V.9 Decontamination Procedures } & 14\end{array}$ 
VI.3 Accident Response Procedures $\quad 18$

VI.3.1 General Procedures $\quad 18$

VI.3.2 Procedures for Emergencies Posing an Immediate Threat to Life, Limb, or Health of One or More Persons in the Exclusion Area. $\quad 18$

VI.3.3 Procedures for Minor Accidents in the Exclusion Area. 19

VI.3.4 Procedures for Emergencies Posing an Immediate Threat to Life, Limb, or Health of One or More Persons in the Contamination Reduction or Support Area.

VI.3.5 Procedures for Minor Accidents in the Contamination Reduction or Support Area. 19

$\begin{array}{ll}\text { VI.4 Accident Reporting Procedures } & 20\end{array}$

$\begin{array}{ll}\text { VI.5 Emergency Contacts } & 20\end{array}$

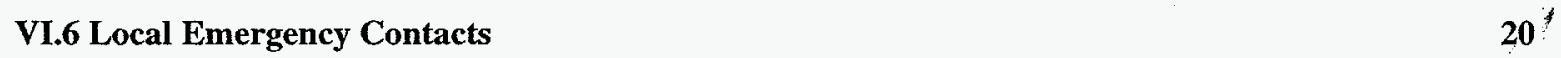

VII. PLAN PREPARATION $21 \%$

$\begin{array}{ll}\text { VIII. CERTIFICATIONS } & 21\end{array}$

\section{FIGURES}

FIGURE V-1 CZECHWICE OIL REFINERY 10

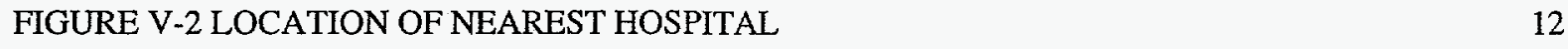

FIGURE VI-1 EMERGENCY ROUTES 16 


\section{Health And Safety Plan \\ For \\ The Czechowice Oil Refinery \\ Bioremediation Demonstration \\ of a Process Waste Lagoon}

\section{Project Overview}

This Health and Safety Plan addresses the third phase of a multi-phase, joint project including the U.S. Department of Energy and the Institute for the Ecology of Industrial Areas in Katowice, Poland. This institute and this region of Poland offer unique opportunities for conducting environmental research, developing and demonstrating environmental remediation technologies and for implementing projects which result in bilateral benefits to the U.S. and Poland.

The specific goals of this project are to demonstrate the methodologies and technologies associated with site characterization, risk assessment and site remediation, using a site in Poland and to provide a mechanism for the transfer of those methodologies and technologies to Poland and other countries in the region.

The project includes the following components:

- Expedited Site Characterization (ESC) - The goal of the characterization component is to collect the information necessary to: identify the nature, extent: and movement of subsurface contamination in order to assess the risks to site workers, nearby residents and the environment, and provide the necessary data for the design and implementation of a site remediation strategy.

- Risk Assessment - The risk posed to humans and the environment by site contamination will be evaluated using appropriate exposure scenarios. Sitespecific, risk-based cleanup goals for the soils and groundwater at the site will be developed.

- Remediation - Based on the results of site characterization and risk assessment, the appropriate remediation technology or technologies will be selected to address the contamination at the site.

\section{Site Overview}

\section{II.1 Site Selection}

The Czechowice Oil Refinery has been selected as the demonstration site for this project based on the suitability of the $e_{o}$ site for the planned demonstrations. An important consideration in the selection process was finding a cooperating partner in Poland that would move quickly and decisively in providing site access and funding needed to complete site preparations necessary for the project. 
The refinery is approximately 100 years old and uses the catalytic cracking process to refine crude oil. The waste stream from the refinery process (a thick, viscous semi-liquid) empties into a series of lagoons. The lagoons contain several million gallons of this heterogeneous and relatively uncharacterized waste product. It is expected that the immediate subsurface is heavily contaminated with hydrocarbons and the deeper subsurface also may be contaminated. The project will demonstrate technologies to characterize, assess and remediate one of these lagoons.

\section{II.2 Site History and Description}

The Czechowice Oil Refinery, started its operation in 1896, when the Schodnica refinery was built. In 1902, in the vicinity of the Schodnica refinery, the construction of a larger and much more competitive modern refinery was started. This second refinery was built by Vacuum Oil Company, which was owned by Socony Vacuum Oil Incorporation, New York.

The first refinery processed 35000 tons of paraffinic crude oil a year. In 1931, the first Foster Wheeler distillation unit in Poland was built at the refinery. The refinery was bombed in August, 1943 by the Allies and only partly rebuilt by the Germans during the war. The restoration was finished by Polish engineers and workers shortly after the end of the World War II. Production resumed in February 1946.

An additional plant was built on the site in 1954 to refine cresol. The original plant was rebuilt with an increased capacity of 25000 tons a year. The capacity of the new part of the refinery was increased in the period of 1959 and 1962 to a capacity of 500000 tons a year. A fire damaged part of the refinery in 1971 but it was rebuilt quickly. In 1985, thallic and turpentine oil processing plants from a separate company were incorporated into the refinery. The refinery is currently being converted into a free market company.

Petroleum is the main raw material and is used to produce the following products: ethyl gasoline, engine oil, fuel oil, paraffins, paraffin products, asphalts, special oil, and oil products. The by-products of these processes, an oil-water sludge, is disposed in three lagoons which cover an area of approximately 3 to 8 ha to a depth of 2 to $3 \mathrm{~m}$. The three lagoons contain a total of approximately 121.4 thousand tons of sludge, rubble and dirt. One of these three lagoons is to be the site of this demonstration

\section{II.3 Site Geography and Local Land Use}

The refinery is located in the eastern part of the town of Czechowice-Dziedzice. Czechowice-Dziedzice is situated in the south-west of Poland, in the southern part of the Katowice province $-45 \mathrm{~km}$ from the city of Katowice, $8 \mathrm{~km}$ from the town of Bielsko-Biala and about $6 \mathrm{~km}$ from Goczalkowice Lake. Czechowice-Dziedzice covered the area of $33 \mathrm{~km}^{2}$ and is inhabited by 35615 people; the population density is 1079 people $/ \mathrm{km}^{2}$. 


\section{SCOPE OF WORK}

III.1 Planned Site Activities and Dates - Bioremediation Demonstration

Febr. 22 -

March 30: Installation of piezometers and preliminary sampling.

April 1 to

May 31:

Support ESC Activities.

June 1 to

Project

Completion: On going Environmental sampling to support project goals.

August 25 to October 15:

Construction, testing and start-up of bioremediation system.

October 15 to

Project

Completion: System optimization, process monitoring, environmental sampling and system demobilization and project close out. Close out projected for October, 1997.

WSRC - up to 3 persons

FSU - up to 3 persons

IETU - up to 10 persons
Refinery - up to 15 persons

Contractors - up to 4 persons

Note: These are maximum numbers and not all of these persons are expected at one time. Actual maximum numbers at any one time are expected to range from 5-15 persons.

\section{III.3 Number of Days to Complete Work}

Approximately 365 workdays. 


\section{WASTE CHARACTERISTICS}

The following information pertains to waste materials which will likely be encountered during the course work at the site:

A. Waste Type(s)

Liquid

$$
\begin{array}{llll}
\mathrm{X} & \text { Solid } & \mathrm{X} & \mathrm{x} \\
\mathrm{X} & \text { Other } &
\end{array}
$$

B. Waste Characteristics

Corrosive

Volatile

Unknown
Radioactive

Reactive 


\section{HAZARD EVALUATION}

\section{IV.1 Chemical Hazards}

Polynuclear aromatic hydrocarbons (PAHs) are known to be associated with refinery sites. Other typical refinery wastes include: oils which contain light aromatics (i.e., benzene, toluene, and xylenes). The following are regulatory standards and advisory levels for the potential chemical constituents at the refinery site.

REGULATORY STANDARDS AND ADVISORY LEVELS

FOR AROMATIC AND PAH COMPOUNDS IN AIR

\begin{tabular}{|c|c|c|c|c|c|}
\hline \multirow[t]{2}{*}{ Compound } & \multirow[t]{2}{*}{ Agency } & \multicolumn{2}{|c|}{$\begin{array}{l}\text { Regulatory Standard } \\
\qquad\left(\mu \mathrm{g} / \mathrm{m}^{3}\right)\end{array}$} & \multicolumn{2}{|c|}{$\begin{array}{l}\text { Advisory Level } \\
\left(\mu \mathrm{g} / \mathrm{m}^{3}\right)\end{array}$} \\
\hline & & 24 hour & 30 minute & 8 hour & 30 minute \\
\hline Benzene & $\begin{array}{c}\text { MEP } \\
\text { MWSP }\end{array}$ & 10 & & 10 & 40 \\
\hline Toluene & $\begin{array}{c}\text { MEP } \\
\text { MWSP }\end{array}$ & 200 & 300 & 100 & 350 \\
\hline Xylene & $\begin{array}{c}\text { MEP } \\
\text { MWSP }\end{array}$ & 100 & 300 & 100 & 350 \\
\hline Ethyl benzene & $\begin{array}{l}\text { NIOSH } \\
\text { MWSP }\end{array}$ & $\begin{array}{l}435000 \\
(10-h r .)\end{array}$ & $\begin{array}{l}545000 \\
(15-\text { min. })\end{array}$ & 100 & 500 \\
\hline Naphthalene & $\begin{array}{l}\text { NIOSH } \\
\text { MWSP }\end{array}$ & $\begin{array}{c}50000 \\
(10-h r .)\end{array}$ & $\begin{array}{c}75000 \\
(15-\mathrm{min} .)\end{array}$ & 20 & 75 \\
\hline
\end{tabular}

Abbreviations:

MEP - Ministry for Environmental Protection (Poland)

MWSP - Ministry for Welfare and Social Policy (Poland)

NIOSH - National Institute of Occupational Health and Safety (USA)

TWA - Time-Weighted Average

COR - Czechowice Oil Refinery

FTL - Field Team Leader

SSO - Site Safety Officer 


\section{IV.2 Physical Hazards}

The demonstration site is located within an operating oil refinery and thus presents the normal hazards associated with a production facility such as slips, trips, and falls. In addition, trucks and other vehicles will be operating on site.

\section{IV.3 Hazards Posed by Site Activities}

Drilling and heavy equipment operation (cone penetrometer, Geoprobe®, and excavation equipment) hazards. Utilities and electrical lines (buried and above ground) are also present on site.

\section{IV.4 Unusual Hazards}

Due to the age and history of the site, many types of unknown materials may be encountered in and around the lagoons. Such materials could possibly include metallic debris, buried cables, wires or pipes. Use of the magnetic locator and GPR (Ground Penetrating Radar) is expected to reduce the possibilities of such, encounters.

\section{IV.5 Overall Hazard Level}

Low: During ground water sampling, hydrogeologic measuring and testing, and surveying low concentrations of contaminants are expected.

Moderate: During drilling, well installation, and source sampling, the potential of exposure to contaminants by inhalation or direct skin contact exists. Mechanical failure or errors from heavy equipment operations also present a potential threat.

\section{PROCEDURES}

\section{V.1 Roles and Responsibilities}

In matters involving health and safety of site workers, the following general roles and responsibilities apply:

Site Safety Officer - The SSO is responsible for overseeing and documenting all activities related to protecting the health and safety of the site workers and 
ensuring that all work activities comply with the safety plan. The SSO is has unrestricted authority over matters related to health and safety.

Field Team Leader - The FTL is responsible for overseeing the technical tasks being performed by the members of the field investigation team. The FTL will report on issues of health and safety to the SSO.

Field Investigation Team Members - Field Team Members are responsible for executing technical tasks under the direction of the FTL. Team members are responsible for performing their tasks in a manner consistent with the safety plan and all safe work practices. Team members will report any unsafe activities or conditions to the SSO and FTL.

\section{V.2 Training Requirements}

All personnel who will be engaged in hazardous waste operations must have completed, within the 12 months prior to the beginning of site activities, a hazardous waste site investigation training course or eight hour refresher course. The training must comparable to that described in OSHA regulations 29 CRIFR 1910.120 et seq.

\section{V.3 Level of Protection}

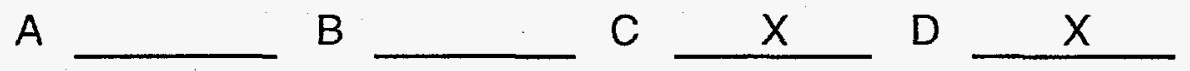

Level D

Tyvek@ coveralls or appropriate chemical-resistant suit Outer gloves - Nitrile rubber or Neoprene Inner gloves - Disposable Latex or Nitrile Boots - Steel toe and shank, impermeable and chemical-protective Outer boot covers - Disposable rubber, impermeable and chemicalprotective

Hard hat (to be worn during drilling operations and when overhead hazards exist)

Hearing protection (to be worn during drilling operations)

Safety glasses or goggles 


\section{Level $\mathrm{C}$}

Full-face, Air-Purifying Respirator (APR) (OSHA/NIOSH-approved) with appropriate cartridges (acid gas and organic vapor).

Tyvek $\circledast$ coveralls or appropriate chemical-resistant suit

Outer gloves - Nitrile rubber or Neoprene

Inner gloves - Disposable Latex or Nitrile

Boots - Steel toe and shank, impermeable and chemical-protective

Outer boot covers - Disposable rubber, impermeable and chemicalprotective

Hard hat (to be worn during drilling operations and when overhead hazards exist)

Hearing protection (to be worn during drilling operations) 


\section{V.4 Action Levels}

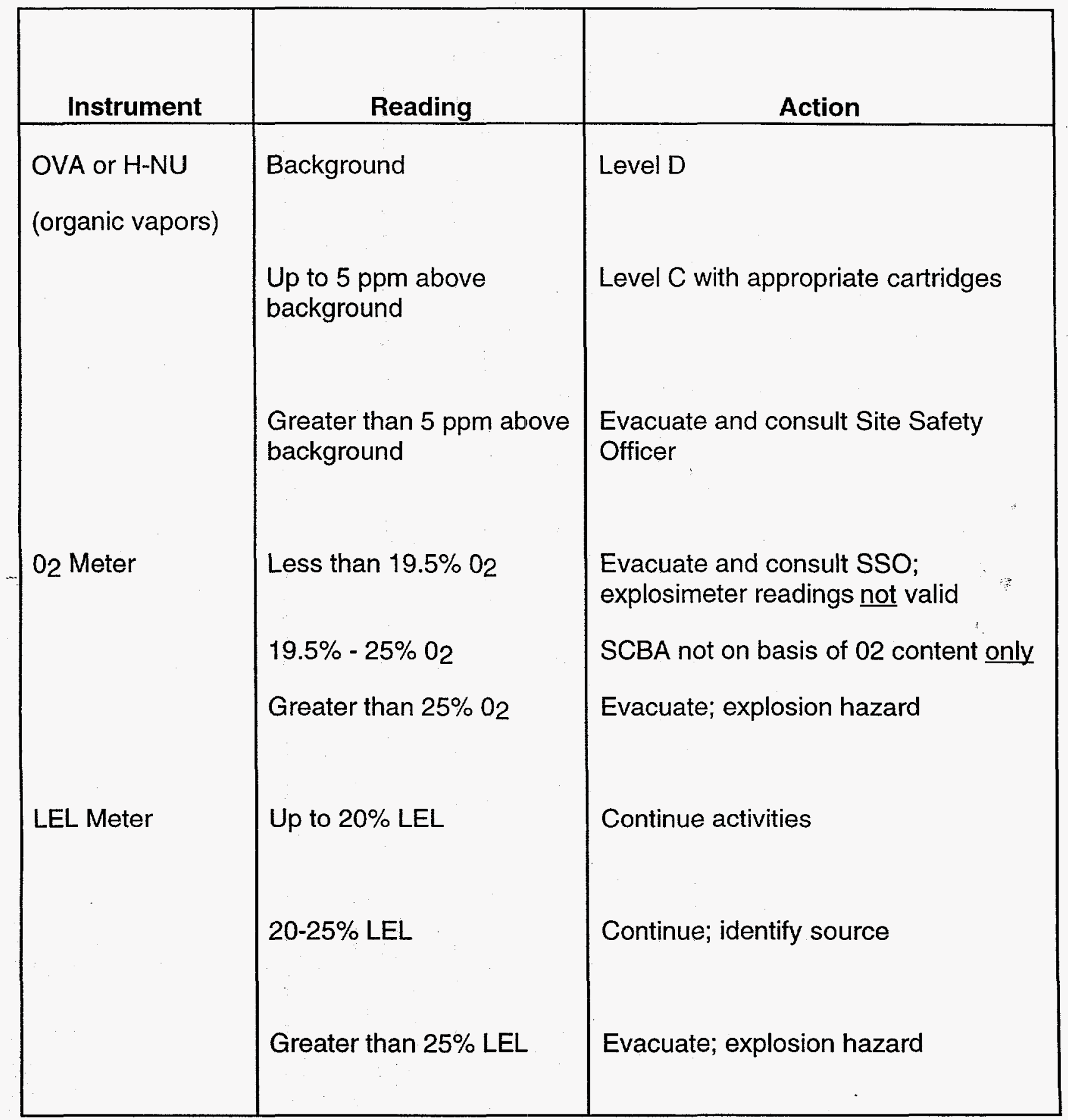




\section{V.5 Monitoring Requirements}

Ambient air monitoring will be conducted continuously while site activities are in progress. Monitoring instruments will include the following:

- $\quad \mathrm{H}-\mathrm{NU}(\mathrm{PID})$ for organic vapors/ B\&K Infared Detector

- $0_{2} / L E L$ meter.

- Dust meter (as required).

The SSO will record instrument readings every 60 minutes or when significant changes occur. Upgrade/downgrade decisions will be based on monitoring results in the breathing zone and the action levels listed above. Hearing protection will be worn during drilling activities, so a noise meter will not be required. Calibration and maintenance of monitoring equipment will be the responsibility of the SSO and will be conducted in accordance with manufacturer's requirements as listed in the appropriate manual.

\section{V.6 Site Organization and Control}

\begin{tabular}{ll} 
Map/Sketch Attached? & Yes \\
\cline { 2 - 2 } Perimeter Identified? & Yes \\
\cline { 2 - 2 } Zone(s) of Contamination Identified? & No \\
\end{tabular}

Note: Work areas within the site (exclusion area, contamination reduction area, support area) should be established so that the support area is upwind and at a higher elevation than the exclusion area.. One or more flags should be placed on site to determine wind direction.

Figure V-1 depicts the location of the Czechowice Oil Refinery site and the nearest available hospital. Figure V-2 shows the layout of the site itself. These drawing will be posted at the site field office and construction area..

The SSO will define the exclusion area, contamination reduction area, and support area before the field activities begin at each sampling location. Entry into and exit from the Exclusion Area for all personnel and equipment will be made through the Contamination Reduction Area. The SSO will be responsible for setup of the 
Figure V-1 Czechwice Oil Refinery

To be provide at the demonstration site. 
Figure V-2 Location of Nearest Hospital

To be provide at the demonstration site. 
personnel and equipment decontamination facilities in the Contamination Reduction Area. All personnel will make a final check of their protective equipment in the Contamination Reduction Area before entering the Exclusion Area. All personnel departing the Exclusion Area will decontaminate and remove their equipment before entering the Support Area.

The Support Area will include an equipment staging and storage area. Emergency telephone numbers, directions to the hospital, and the Site Safety Plan will be available in the Support Area. A First-Aid kit will also be located in the Support Area. A vehicle designated for emergency service will be parked within or near the Support Area.

\section{V.7 Initial Procedures}

- Locate nearest available telephone.

- Confirm and post emergency telephone numbers and route to hospital.

- Designate at least one vehicle for emergency use.

- Determine prevailing wind location and establish preliminary work areas (support area, contamination reduction area, exclusion area).

- Perform initial site reconnaissance.

- Hold safety briefing for all participants before work begins.

\section{V.8 Work Limitations}

- No eating, drinking, chewing of gum or tobacco, or smoking in the exclusion and contamination reduction zones.

- No contact lenses to be worn in the exclusion and contamination reduction zones.

- Work restricted to daylight hours only.

- Buddy system to be used at all times in exclusion zone.

- Work to stop during thunderstorms or electrical storms.

- No facial hair that would interfere with respirator fit. 


\section{V.9 Decontamination Procedures}

For Personnel:

Level D

Remove overboots and dispose of.

Remove outer gloves and dispose of as necessary.

Remove Tyvek $\circledast$ or chemical-resistant suit and dispose of as necessary.

Remove inner gloves and dispose of.

Shower immediately after work.

Level C

Remove overboots and dispose of.

Remove outer gloves and dispose of as necessary.

Remove Tyvek@ or chemical-resistant suit and dispose of as necessary.

Remove APR, remove cartridges and dispose of and decontaminate respirator.

Remove inner gloves and dispose of.

Shower immediately after work.

For Equipment:

After using monitoring equipment, wipe surfaces of equipment with a cloth that has been dampened with a solution of laboratory detergent and water. When not in use, monitoring equipment contamination will be prevented by placing the items in plastic bags or in the appropriate carrying case. Dispose of plastic bags after use.

For drilling and sampling equipment, follow instructions specified in the drilling specification and Work Plan.

For Vehicles:

Properly decontaminate all vehicles entering the exclusion or contamination reduction zones.

All soil, gravel, or particulates must be removed by a high pressure spray or by scrubbing with soap and water.

All runoff must be collected and disposed of in appropriate drums.

For the drill rig, follow the instructions in the drilling specifications. 


\section{V.10 Disposal Procedures}

Used Protective Clothing and Miscellaneous Wastes:

Used protective clothing and other miscellaneous wastes will be bagged and disposed of through routine waste disposal procedures at the Czechowice Oil Refinery.

\section{V.11 Safety Equipment}

- Fire extinguishers

- Eye-wash bottles

- First aid kit

\section{EMERGENCY INFORMATION}

\section{VI.1 Emergency Routes}

Emergency routes at the refinery site are depicted in Figure $\mathrm{VI}-1$ - Emergency Response Plan.

\section{Vl.2 Contingency Plan}

General Information

The Field Team Leader or SSO will contact the local hospital emergency room, police department, fire department, ambulance, and other emergency services before field activities begin. The Field Team Leader or SSO will inform the hospital emergency room and ambulance service of probable emergencies and provide necessary information to the hospital prior to the start of the investigation. This will assist local personnel in being prepared should an emergency arise during investigation.

The SSO will be responsible for establishing, then adjusting as necessary, appropriate levels of eye, skin, and respiratory protection for the investigation. The SSO will ensure that all participants conduct their work in accordance with the Site Safety Plan and applicable safety rules and will direct any assigned employee to 
Figure VI-1 Emergency Routes

To be provide at the demonstration site. 
leave the site if he or she fails to observe safety requirements or in any way creates a safety hazard.

At ambient temperatures of $7^{\circ} \mathrm{C}$ or below, hourly warm-up breaks will be taken, and cold stress monitoring will be implemented. Warm beverages may be given. At ambient temperatures of $27^{\circ} \mathrm{C}$ or above, hourly breaks will be taken, and heat stress monitoring will be implemented. Cold beverages may be given to replenish fluids. In either event, work schedules will be adjusted as required.

All employees will be directed to bring to the attention of the Field Team Leader and SSO any unsafe condition, practice, or circumstance associated with or resulting from the investigation.

In cases of immediate hazard to employees or the public, employees on the scene will take all practical steps to eliminate, neutralize, or avoid the hazard. This may include leaving the site. The Field Team Leader will take the steps necessary to ensure that the investigation is completed safely. These steps may include changes in field procedures, removal or neutralization of a hazard, consultation with appropriate experts, or use of specialists. All such actions will be coordinated with and approved by the Site Safety Officer.

\section{Site Safety Briefings}

Before the demonstration begins, the SSO will hold a site briefing. All members of the investigation team, including contractors, will attend this meeting. During this meeting, the SSO will discuss safety equipment use, maintenance, and limitations; accident reporting procedures; and decontamination procedures. Questions about the project will be answered, and the Site Safety Plan Certification will be signed by all team members during the initial briefing. The SSO will also hold a similar meeting with individuals who later become a part of the demonstration team before they take part in investigation activities. Subsequent periodic briefings will be held throughout the course of the demonstration, especially when unsafe practices are noted or a change in site conditions requires modification of the Site Safety Plan.

\section{Visitors}

Occasionally a situation will arise in which someone visits a site during site activities. In general, most visitors will be accommodated by being permitted to observe activities from the Support Zone. Visitors who present to the SSO certification of completion of a hazardous waste site investigation training course or refresher course (in the last 12 months) in compliance with U.S. OSHA regulations will generally be granted access, provided that they are dressed in suitable protective equipment, they assume all responsibility, and the site owners do not object. Visitors without the training course who desire access to the Exclusion Zone must obtain permission from the owners and the SSO. All visitors, who enter the Exclusion Zone and/or Contamination Reduction Zone will be advised of the nature and level of exposure likely as a result of project-related activities and that they and 
their employees must assume all risk. Copies of this Site Safety Plan will be provided to these persons for informational purposes only.

\section{VI.3 Accident Response Procedures}

\section{VI.3.1 General Procedures}

In the event that any member of the field demonstration team experiences any adverse effects or symptoms of exposure during an investigation activity, the individuals involved with the particular demonstration activity will leave the Exclusion Area and seek appropriate medical aid for the affected individual. The SSO will be in charge of health and safety measures. If he or she is not present or injured, the Field Team Leader will be in charge.

In the event that any member of the field demonstration team is overcome, incapacitated, or traumatically injured while on site, the remaining members will immediately don appropriate protective equipment and make reasonable efforts to rescue the affected person. Once removed from the area where the incident occurred, the affected person will not be left unattended, and medical assistance will : be summoned. If it is necessary to drive the victim to the hospital, two field personnel will accompany the victim. One other person from the field crew will be designated by the SSO to call ahead to the emergency room and provide information about the accident before the victim arrives. If the SSO is injured, the Field Team Leader will designate a person to call ahead to the hospital. If possible, limited decontamination will be conducted, but not if time is critical to get the injured person to medical aid. If it is determined that the problem was due to chemical exposure, all members of the party exposed to those chemicals will proceed expeditiously, in a group, to the hospital. In those cases where personal contamination has occurred, all persons involved will make every reasonable effort to decontaminate themselves to minimize spreading of contaminants.

VI.3.2 Procedures for Emergencies Posing an Immediate Threat to Life, Limb, or Health of One or More Persons in the Exclusion Area.

\{Examples: explosion, excessive smoke, fire, excessive concentrations of organic contaminants, equipment accident, person unconscious, nausea, dizziness, safety or protective equipment malfunction.\}

(1) Any person involved in or witnessing an accident or other threatening situation will notify the other personnel immediately.

(2) Injured persons' partners or other personnel close to them will lend assistance. Personnel will not unduly jeopardize their own lives to assist an injured person. The injured peršon will be moved only when necessary to avoid further hazards. 
(3) All activity in the Exclusion Area will cease and personnel not involved in providing assistance to the injured or endangered personnel will depart to the Support Area.

(4) The SSO will immediately call the proper authorities (ambulance, fire, police, rescue teams, etc.). If the SSO is injured or absent, the Field Team Leader will call the proper authorities.

(5) Personnel will not reenter the Exclusion Area until allowed by the SSO or Field Team Leader. The SSO or Field Team Leader will assess the nature of the emergency and correct the matter before allowing re-entry.

(6) A complete written report of the incident will be made by the injured personnel and the SSO or Field Team Leader and sent to the AL/TIP Site Safety Coordinator.

VI.3.3 Procedures for Minor Accidents in the Exclusion Area.

\{Examples: sprains, small cuts or scrapes, equipment malfunction.\}

(1) The person injured will cease work, notify his/her partner, and exit with the partner to the Support Area and obtain adequate medical attention or equipment repair.

VI.3.4 Procedures for Emergencies Posing an Immediate Threat to Life, Limb, or Health of One or More Persons in the Contarnination Reduction or Support Area.

(1) Persons at the scene will lend assistance and perform the necessary first aid, CPR, etc.

(2) The SSO will immediately call the proper authorities (ambulance, fire, police, poison control center, rescue teams, etc.). If the SSO is injured or absent, the Field Team Leader will call the proper authorities.

(3) Personnel in the Exclusion Area will be signaled to depart the Exclusion Area if they could be affected by the accident.

(4) A complete written report of the incident will be made by the injured personnel and the SSO or Field Team Leader. The report will be sent to the SSO.

VL.3.5 Procedures for Minor Accidents in the Contamination Reduction or Support Area. 
The person involved will initiate the appropriate corrective measures and obtain adequate medical attention. A notation of the injury will be entered into the field record book or notebook by the SSO and FTL.

\section{VI.4 Accident Reporting Procedures}

All accidents will be reported immediately to the Site Safety Officer so that corrective actions can be implemented. If immediate notification is not possible, the accident will be reported within 24 hours of occurrence.

\section{VI.5 Emergency Contacts}

A list of emergency contacts (i.e. police, fire, hospital, etc.) will be provided at the demonstration site.

\section{VI.6 Local Emergency Contacts}

A list of local site emergency contacts (site safety officer, field team leaders, site emergency response team, etc.) will be provided at the demonstration site. 
VII. PLAN PREPARATION

PREPARED BY:

(Site Safety Officer)

REVIEWED BY:

(Site Manager/Project Manager)

Date:

Date:

\section{CERTIFICATIONS}

By my signature, I certify that:

1. I have read, and

2. I understand, and

3. I will abide by the Site Safety Plan for the Czechowice Oil Refinery site.

NAME

SIGNATURE

DATE

AFFILIATION 


\section{CERTIFICATIONS (continued)}

By my signature, I certify that:

1. I have read, and

2. I understand, and

3. I will abide by the Site Safety Plan for the Czechowice Oil Refinery site.

NAME

SIGNATURE

DATE

AFFILIATION 


\section{CERTIFICATIONS (continued)}

By my signature, I certify that:

1. I have read, and

2. I understand, and

3. I will abide by the Site Safety Plan for the Czechowice Oil Refinery site.

NAME SIGNATURE DATE AFFILIATION




\section{CERTIFICATIONS (continued)}

By my signature, I certify that:

1. I have read, and

2. I understand, and

3. I will abide by the Site Safety Plan for the Czechowice Oil Refinery site.

NAME SIGNATURE

